\title{
Strategy for lead identification for understudied kinases
}

\author{
David H. Drewry ${ }^{1,2,3}$, Joel K. Annor-Gyamfi ${ }^{1,2}$, Carrow I. Wells ${ }^{1,2}$, Julie E. Pickett ${ }^{1,2}$, Alison D. Axtman ${ }^{*, 1,2}$ \\ ${ }^{1}$ Structural Genomics Consortium, UNC Eshelman School of Pharmacy, University of North Carolina at Chapel Hill, Chapel \\ Hill, NC, 27599, USA \\ ${ }^{2}$ Division of Chemical Biology and Medicinal Chemistry, UNC Eshelman School of Pharmacy, University of North Carolina \\ at Chapel Hill, Chapel Hill, NC, 27599, USA \\ ${ }^{3}$ UNC Lineberger Comprehensive Cancer Center, UNC Eshelman School of Pharmacy, University of North Carolina at \\ Chapel Hill, Chapel Hill, NC, 27599, USA
}

\begin{abstract}
The pyrimidine core has been utilized extensively to construct kinase inhibitors. In fact, 8 FDA-approved drugs targeting kinases bear a pyrimidine core that makes key hydrogen bond interactions with the crucial hinge region shared by most human kinases. Because the pyrimidine hinge-binding motif is accommodated by many kinases within the larger kinome, kinome-wide selectivity of resultant molecules can be poor. In our quest to create useful inhibitors for all human kinases, this liability was seen as an advantage since it is well tolerated by many understudied kinases. We hypothesized that small sets of non-exemplified pyrimidines based on selected literature examples would provide us with useful inhibitors of these lesser studied kinases. As proof of concept, we designed a small library of inhibitors that incorporated the side chains from some well-annotated pyrimidine-based kinase inhibitors of TBK1 that also displayed activity on understudied kinases of interest. Our strategy paired mixing and matching the side chains from the 2- and 4positions of the parent compounds with modifications at the 5-position of the pyrimidine core, which is situated near the gatekeeper residue of the binding pocket. We reasoned that these targeted changes in three positions would provide sufficient structural diversity to uncover useful structure-activity relationships (SAR) for understudied kinases. Utilizing this approach, we imparted improved kinome-wide selectivity to most members of the resultant library. Importantly, we also identified potent biochemical and cell-active lead compounds that can be further developed into chemical probes for understudied kinases like DRAK1 and MARK3/4. Our studies demonstrate that pyrimidine-based kinase inhibitors can be converted to selective, cell-active inhibitors for lesser studied kinases. Furthermore, we provide a simple strategy that can be employed with other kinase scaffolds to identify tools for understudied kinases.
\end{abstract}

\section{INTRODUCTION}

Pyrimidines represent an important building block in the medicinal chemistry arsenal. Compounds bearing a pyrimidine core have proven to be bioactive and exhibit diverse pharmacology, including anti-convulsant, analgesic, sedative, anti-depressive, anti-pyretic, anti-inflammatory, anti-viral, anti-HIV, anti-microbial, and antitumor activities. ${ }^{1}$ Pyrimidines are very useful as kinase scaffolds because the pyrimidine nitrogen and an $\mathrm{NH}$ in the 2-position make key hydrogen bonds with the conserved hinge region found in nearly all human kinases. To date, 8 FDA-approved kinase inhibitors employ a pyrimidine as the key kinase hinge-binding motif. ${ }^{2}$

The work we describe here stems from the synergistic convergence of two separate interests that were satisfied through diversification of the pyrimidine scaffold. The first of these interests centers around the generation and use of kinase inhibitors as tools to build deeper understanding of signaling in neurodegenerative disease. TBK1, a kinase with links to amyotrophic lateral sclerosis (ALS), frontotemporal dementia (FTD), Huntington's disease, and Alzheimer's disease $(\mathrm{AD})$, is potently inhibited by a number of pyrimidine-bearing compounds. ${ }^{3-12}$ A second interest of ours is identification of high-quality tool molecules for understudied kinase targets. Our pursuit of this interest relies on parallel chemical tool and kinase assay development, efforts that are supported in part by the NIH Illuminating the Druggable Genome (IDG) program. The IDG program aims to catalyze the characterization of all proteins through stimulating research around those that are most poorly studied. ${ }^{13}$ One arm of the IDG program supports illumination of the dark kinome, which includes development of high-quality chemical tools for these understudied kinases. As we examined the data available for literature pyrimidine-based TBK1 inhibitors, we noticed a range of understudied kinases that were also inhibited by these compounds.

Several of the understudied kinases inhibited by pyrimidines also have been genetically implicated in driving neurodegenerative diseases. The MARK family of kinases, for example, phosphorylate tau protein in its repeat domain and thereby regulate its affinity for microtubules, affecting the aggregation of tau into neurofibrillary tangles. Observations of $\mathrm{AD}$ brains show a strong correlation between cognitive dysfunction and cortical neurofibrillary tangle density. ${ }^{14-16}$ Mutations in tau have also been shown to cause a form of FTD. ${ }^{16}$ Furthermore, with a characterized role in dendrite branching and spine development, understudied kinase AAK1 plays a role in several neurodegenerative disorders, including $\mathrm{AD}$ and 

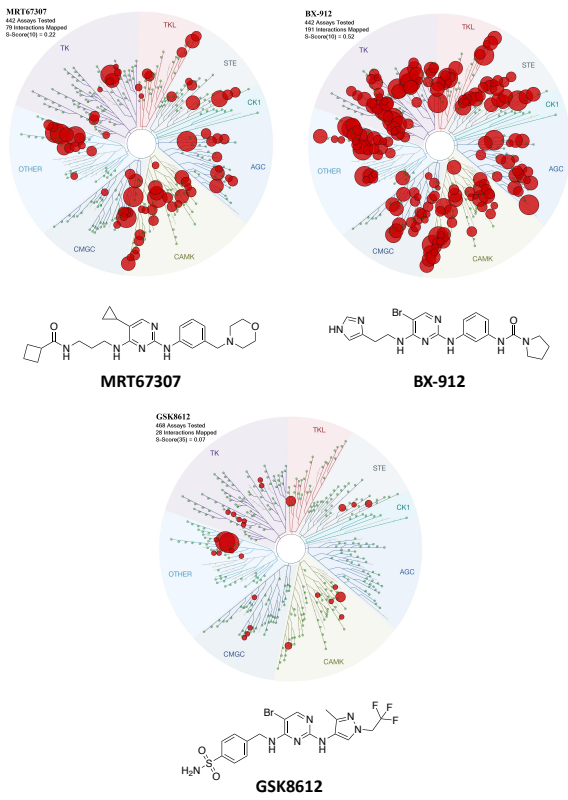

Figure 1. Structures and broad selectivity profiling of pyrimidine-based inhibitors that served as the basis for library design. All wild-type kinases inhibited $>90 \%$ at $10 \mu \mathrm{M}$ by MRT67307 and BX-912 and all wild-type kinases inhibited $>65 \%$ at $1 \mu \mathrm{M}$ by GSK8612 are shown.
ALS. ${ }^{14,17,18}$

Figure 1 shows the structures and kinome-wide profiling data generated at DiscoverX (scanMAX or KINOMEscan) for three TBK1-targeting pyrimidines. ${ }^{19}$ The data for TBK1 inhibitors MRT67307 and BX-912 (designed for PDK1 but potent inhibitor of TBK1) is already in the literature (LINCS database). ${ }^{20-24}$ These two compounds were screened at $10 \mu \mathrm{M}$ (Figure 1). GSK8612 was recently disclosed by GlaxoSmithKline as a potent and selective TBK1 inhibitor. ${ }^{25}$ We opted to survey the kinome-wise selectivity of GSK8612 at DiscoverX at $1 \mu \mathrm{M}$ (Figure 1). While the screening concentrations are different, it is apparent that these scaffolds differentially and potently inhibit many kinases across the kinome, and that selectivity can be augmented through structural changes.

Several kinases potently inhibited by pyrimidines like BX-912, MRT67307, and/or GSK8612 are members of the IDG nominated list of dark kinases. Thus, this scaffold was considered an excellent starting point from which to design high-quality chemical tools. Development of these tools will enable elucidation of the function of those kinases that have suffered from a dearth of characterization, including those on the IDG list. Our high-quality chemical tools will also enable further characterization of kinase-mediated signaling in neurodegenerative disease and facilitate the validation of therapeutic hypotheses.

Table 1. Selectivity profiling data for pyrimidine library

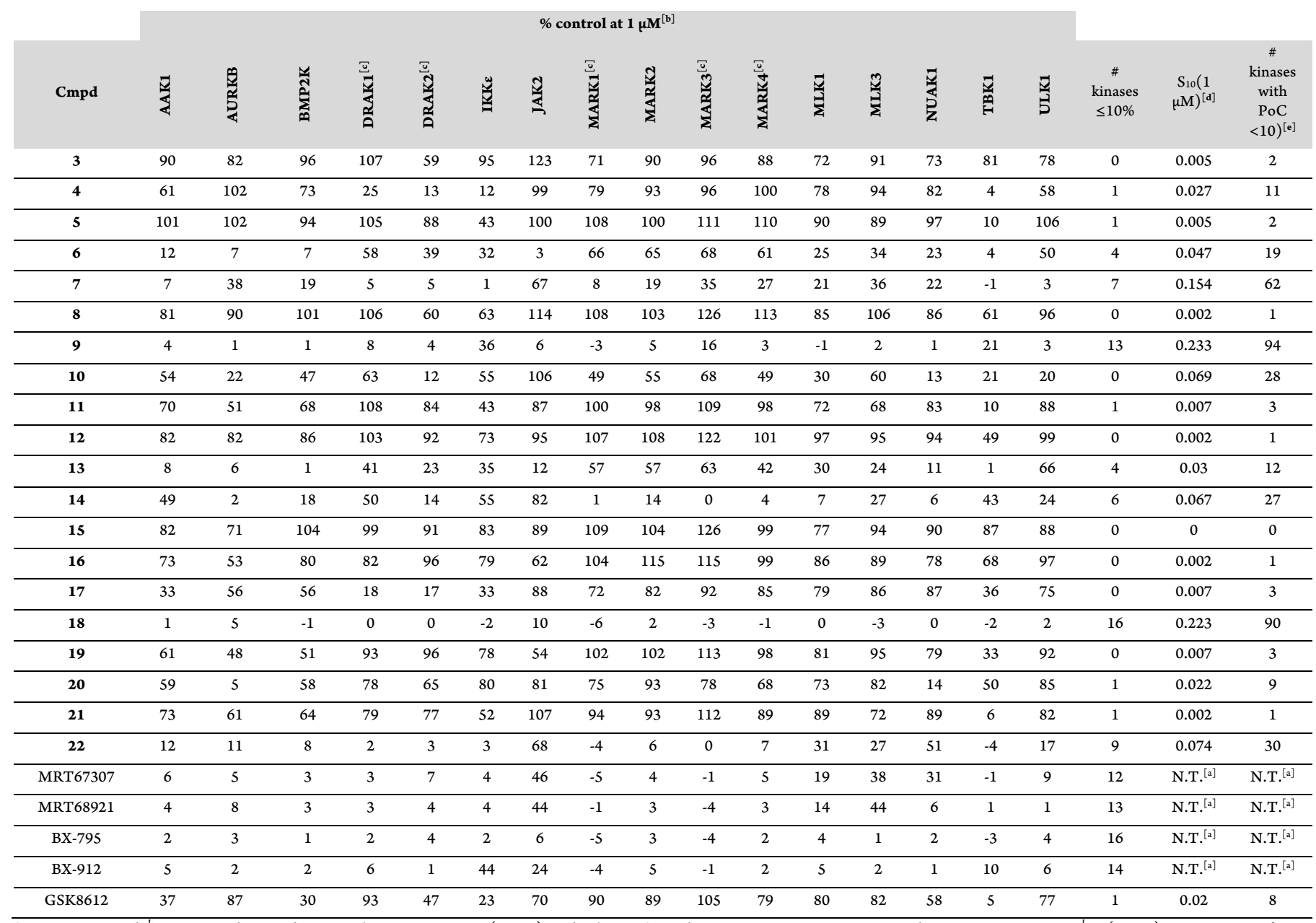

${ }^{a}$ N.T.: not tested. ${ }^{b}$ Compounds tested at a single concentration $(1 \mu \mathrm{M})$ in duplicate. ${ }^{c}$ IDG kinase; DRAK1 = STK17A and DRAK2 = STK17B. ${ }^{d} S_{10}(1 \mu \mathrm{M}):$ percentage of screened kinases with percent of control (PoC) values $<10$ at $1 \mu \mathrm{M}$. ${ }^{e}$ Number of kinases with PoC values $<10$ at $1 \mu \mathrm{M}$. 


\section{RESULTS AND DISCUSSION}

Compound Design and Synthesis. Our library design involved mixing and matching the side chains and cores from published pyrimidine-based inhibitors MRT67307, BX-912, and GSK8612 to furnish 21 total analogs. Specifically, we paired mixing and matching the side chains from the 2-and 4-positions of the parent compounds with modifications at the 5-position of the pyrimidine core as shown in the box in Scheme 1. Seven final compounds were prepared with $\mathrm{X}=\mathrm{H}$, seven with $\mathrm{X}=\mathrm{Br}$, and seven with $\mathrm{X}=$ cyclopropyl (Figure 2). Analogs of BX-912 and MRT67307 (and the parent compounds themselves) that varied only at the 5-position (box in Scheme 1) were not prepared. A great deal of effort has been dedicated to making close structural analogs of these two compounds and we did not want our work to be redundant. Since it was not commercially available at the time and the most selective of the parent scaffolds, GSK8612 and variants with $\mathrm{X}=\mathrm{H}$ and cyclopropyl were all synthesized. The method used to prepare these analogs is outlined in Scheme 1. Briefly, taking advantage of the inherent reactivity of 2,4-dichloropyrimidines, iterative amine couplings were executed, and specific brominated compounds (GSK8612, 6, 9, 10, and 13) were subsequently dehalogenated to furnish all final compounds.

We had several expected outcomes from our strategy of mixing and matching the side chains and cores from well exemplified pyrimidine-based inhibitors. Firstly, we intended to develop more narrowly selective compounds by incorporating these distinct side chains and 5-position modifications into new compounds. Next, we wanted to generate preliminary SAR for several understudied kinases. In doing so we aimed to leverage these scaffolds with known inhibitory activity of dark kinases to identify more optimal chemical starting points for development of high-quality chemical tools. Finally, we wanted to develop focused SAR around the 5-position (box in Scheme 1), which has not been systematically investigated in the literature yet is proposed to play a key role in dictating both potency and selectivity due to its proximity to the kinase gatekeeper residue.

Scheme 1. Library design and preparation strategy. Step A: Pyrimidine 1, Amine 1, DIPEA, ethanol, $-10^{\circ} \mathrm{C}$ to $50^{\circ} \mathrm{C}$; Step B: Pyrimidine 2, Amine 2, Dioxane $\times \mathrm{HCl}$, butanol, $80^{\circ} \mathrm{C}$; Step C: Pyrimidine 3, 5\% Pd/C, $\mathrm{H}_{2}$, TEA, methanol, r.t.

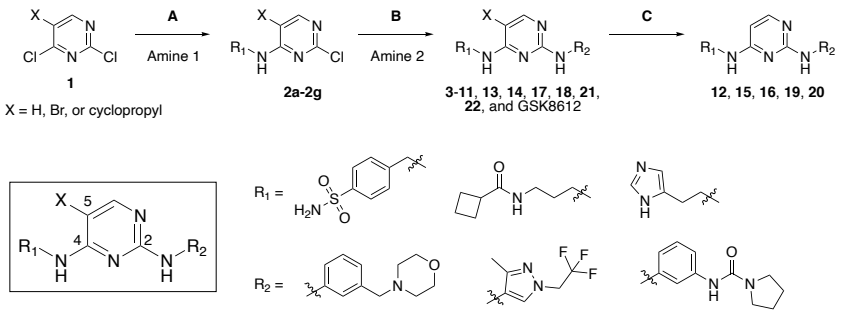

Targeted Kinase Selectivity Profiling. We selected a small panel of representative kinases against which to profile our library of 21 pyrimidine analogs. These kinases include some of the original targets for which pyrimidine-based inhibitors were prepared (JAK2, $\mathrm{IKK}$, TBK1, and ULK1), a more well-studied kinase that is potently inhibited by many analogs within this structural class (AURKB), and several understudied kinases, many of which are both on the IDG list (AAK1, BMP2K, DRAK1-2, MARK1-4, MLK1, MLK3, and NUAK1) and of interest in the neuroscience space. ${ }^{14,15,17,26-29}$ We profiled our pyrimidine series and the parent pyrimidines that influenced our design against this kinase panel at a single concentration $(1 \mu \mathrm{M})$ in radiometric enzymatic assays at Eurofins at the $\mathrm{Km}=\mathrm{ATP}$ for each kinase. Table 1 shows the results of this study, where \% control is reported for each compound for each kinase and lower values indicate greater inhibition. The column labeled "\# $\leq 10 \%$ " captures the number of kinases in this 16 -member panel inhibited $\geq 90 \%$ by each compound.

We found that, with the exception of 2 analogs, all compounds in our library were more selective in this custom kinase panel than published compounds BX-912, BX-795, MRT67307, and MRT68921. ${ }^{20-23}$ In most cases we demonstrated a significant increase in selectivity. Gratifyingly, unlike the published compounds from the BX and MRT series that elicited potent inhibition of nearly all kinases in the panel, our compounds have cleaned-up profiles and we were able to dial out inhibition of certain kinases through structural modification. We were pleased to observe potent inhibition of several understudied kinases by some of our more selective analogs, including BMP2K by 6; AAK1, DRAK1, DRAK2, and MARK1 by 7; AAK1 and BMP2K by 13; and MARK1, MARK3, MARK4, MLK1, and NUAK1 by 14.
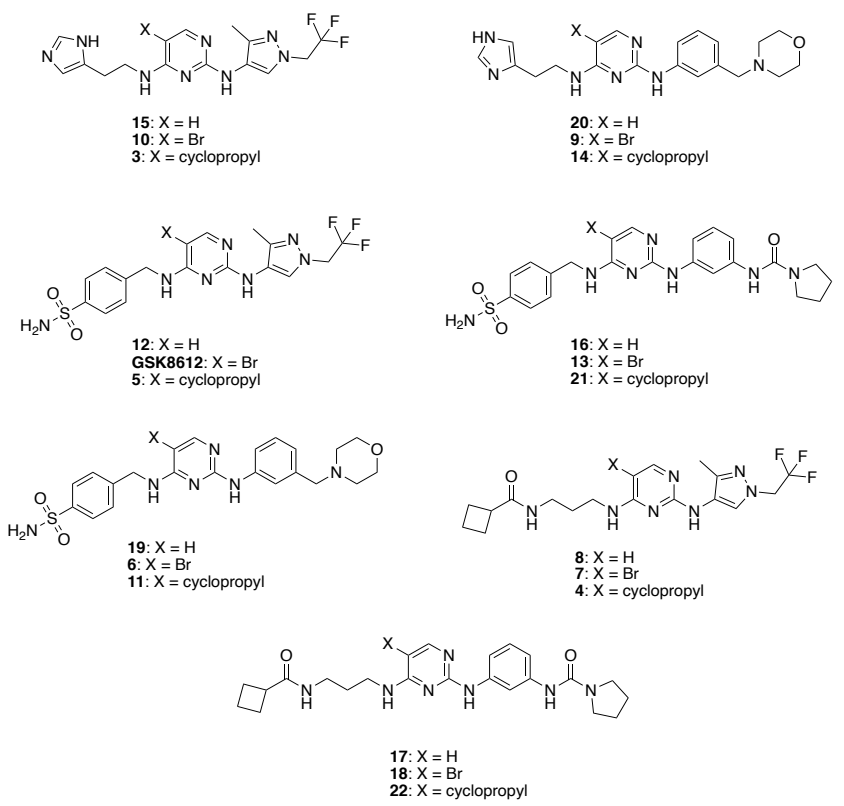

Figure 2. Library of pyrimidine analogs prepared.

When we examined the data generated via screening in the Eurofins kinase panel versus compound structures for our synthetic library, we noticed some predominating trends. When varying the 5position ( $\mathrm{X}$ in Figure 2), the greatest number of kinases were tolerant of the bromo substituent and thus those analogs bearing $\mathrm{X}$ $=\mathrm{Br}$ inhibited the most kinases. When $\mathrm{X}=\mathrm{Br}$, an average of 6.4 kinases were inhibited $\geq 90 \%$ (range of $0-16$ kinases). Switching to $\mathrm{X}=\mathrm{H}$ resulted in the most selective compounds in the series, with an average of only 0.1 kinases demonstrating $\geq 90 \%$ inhibition in the Eurofins panel at $1 \mu \mathrm{M}$ (range of $0-1$ kinase). Finally, cyclopropyl at position $\mathrm{X}$ was somewhere between $\mathrm{H}$ and $\mathrm{Br}$ in terms of selectivity, with an average of 2.7 kinases inhibited $\geq 90 \%$ (range of $0-9$ kinases). When considering the amine side chains in the 2- and 4-positions, some general selectivity trends were also observed. Incorporation of the sulfonamide-bearing side chain in the pyrimidine 4-position $\left(\mathrm{R}_{1}\right.$ position, Scheme 1) resulted in the most selective compounds, inhibiting an average of 1.3 kinases $\geq 90 \%$ at $1 \mu \mathrm{M}$ (range of $0-4$ kinases). In the pyrimidine 2-position, the $\mathrm{R}_{2}$ substituent that yielded the most selectivity within the panel is the substituted 
pyrazole, which inhibited an average of 1.1 kinases $\geq 90 \%$ (range of 0-7 kinases). The ortho-methyl group on the pyrazole ring likely contributes to this enhanced selectivity when compared to other side chains at the $\mathrm{R}_{2}$ position.

Library-wide Cellular Target Engagement Studies. The data generated by screening our pyrimidine analogs in the panel of kinases at Eurofins motivated follow-up cell-based studies. We used cellular target engagement assays to determine whether potent enzyme inhibition corresponded with potent binding in cells. The NanoBRET assay offers a method through which cellular penetrance and binding of a compound to its kinase target in cells can be simultaneously assessed. ${ }^{30}$ Given the consistently potent inhibition of TBK1 by nearly all compounds in our library (Table 1) and our interest in this kinase, we profiled the entire library using the TBK1 NanoBRET assay in dose-response format (Table 2). We found that potent enzymatic inhibition of TBK1 did not always translate to potent engagement of TBK1 in cells. All compounds that demonstrated $50 \%$ inhibition at $10 \mu \mathrm{M}$ when tested using the TBK1 NanoBRET assay in the first dose-response experiment were followed up with two additional replicates. Two members of our library, 7 and 18, and GSK8612 demonstrated sub-micromolar $\mathrm{IC}_{50}$ values in the TBK1 NanoBRET assay. The validation of GSK8612 as a potent, cell-active compound targeting TBK1 aligns well with the recent publication that described its development and characterization. $^{25}$

Shifting our attention to understudied kinases, we also observed that some of our compounds potently inhibited DRAK1, MARK3, and MARK4. As part of the IDG program, we have interest in developing high-quality chemical tools to help elucidate the function of these poorly characterized kinases. For our pyrimidine series, dose-response NanoBRET analysis yielded 5 analogs $(4,7,9$, 18, and 22) and MRT67307 with sub-micromolar activity in the DRAK1 NanoBRET assay. We repeated NanoBRET dose-response on these six compounds and found all to maintain activity over three replicates. Finally, the entire series was tested in the MARK3 and MARK4 NanoBRET assays. We found 4 compounds $(\mathbf{9}, \mathbf{1 4}, \mathbf{1 8}$, and 22) with sub-micromolar $I_{50}$ values in the MARK 4 NanoBRET assay, 2 of which (9 and $\mathbf{1 8})$ also demonstrated sub-micromolar $\mathrm{IC}_{50}$ values in the MARK3 NanoBRET assay. Several of the parent compounds also had sub-micromolar $\mathrm{IC}_{50}$ values in the MARK3/4 NanoBRET assays. Based on our 16-kinase enzyme inhibition panel (Table 1), we felt confident that some of these understudied kinase chemical leads were more selective than their parent compounds, and we chose to assess their kinome-wide selectivities to determine whether they require further optimization in our pursuit of highquality chemical tools.

Table 2. NanoBRET profiling of entire pyrimidine library

\begin{tabular}{ccccc} 
& \multicolumn{4}{c}{ IC $_{\text {so values }}(\mathbf{n M})$} \\
Cmpd & DRAK1 $^{[\mathbf{b}]}$ & MARK3 $^{[\mathbf{c}]}$ & MARK4 $^{[\mathbf{c}]}$ & TBK1 $^{[\mathbf{b}]}$ \\
$\mathbf{3}$ & $>10000$ & $>10000$ & $>10000$ & $>10000$ \\
\hline $\mathbf{4}$ & $874 \pm 103$ & $>10000$ & $>10000$ & $2680 \pm 230$ \\
\hline $\mathbf{5}$ & $>10000$ & $>10000$ & $>10000$ & 7456 \\
\hline $\mathbf{6}$ & $>10000$ & $>10000$ & $>10000$ & $>10000$ \\
\hline $\mathbf{7}$ & $126 \pm 27.6$ & $>10000$ & 3537 & $321 \pm 2.49$ \\
\hline $\mathbf{8}$ & $>10000$ & $>10000$ & $>10000$ & $>10000$ \\
\hline $\mathbf{9}$ & $638 \pm 91.1$ & 872 & 214 & $>10000$ \\
\hline $\mathbf{1 0}$ & $>10000$ & $>10000$ & 8445 & $>10000$ \\
\hline
\end{tabular}

\begin{tabular}{|c|c|c|c|c|}
\hline 11 & $>10000$ & $>10000$ & $>10000$ & $2050 \pm 196$ \\
\hline 12 & $>10000$ & $>10000$ & $>10000$ & $>10000$ \\
\hline 13 & $>10000$ & $>10000$ & $>10000$ & $6170 \pm 2190$ \\
\hline 14 & 3622 & 4015 & 808 & $>10000$ \\
\hline 15 & $>10000$ & $>10000$ & $>10000$ & $>10000$ \\
\hline 16 & $>10000$ & $>10000$ & $>10000$ & $>10000$ \\
\hline 17 & 2311 & $>10000$ & $>10000$ & $>10000$ \\
\hline 18 & $4.47 \pm 0.406$ & 137 & 72 & $338 \pm 22.5$ \\
\hline 19 & $>10000$ & $>10000$ & $>10000$ & $>10000$ \\
\hline 20 & $>10000$ & $>10000$ & $>10000$ & $>10000$ \\
\hline 21 & $>10000$ & $>10000$ & $>10000$ & $>10000$ \\
\hline 22 & $58.2 \pm 3.21$ & 2001 & 509 & $2580 \pm 215$ \\
\hline MRT67307 & $43.2 \pm 2.69$ & $328 \pm 38.5$ & 319 & N.T.[a] \\
\hline MRT68921 & N.T. ${ }^{[a]}$ & 95 & N.T. ${ }^{[a]}$ & N.T. ${ }^{[a]}$ \\
\hline BX-795 & N.T. ${ }^{[a]}$ & 515 & N.T. ${ }^{[a]}$ & N.T. ${ }^{[a]}$ \\
\hline BX-912 & N.T.[a] & 3333 & $338 \pm 4.5$ & 2327 \\
\hline GSK8612 & $>10000$ & $>10000$ & $>10000$ & $339 \pm 39.5$ \\
\hline
\end{tabular}

${ }^{a}$ N.T.: not tested. ${ }^{b}$ Compounds tested in singlicate $(\mathrm{n}=1)$ in dose-response where error not shown, compounds with SEM tested in triplicate $(n=3)$ in doseresponse. ${ }^{c}$ Compounds tested in singlicate $(n=1)$ in dose-response where error not shown, compounds with SEM tested in duplicate $(n=2)$ in dose-response.

Assessment of Kinome-wide Selectivity. The promising selectivity of our pyrimidine series in the custom enzymatic assay panel motivated a broader survey to ascertain the kinome-wide selectivity of our library. All 21 novel analogs were screened at $1 \mu \mathrm{M}$ via the DiscoverX scanMAX platform, which includes 403 wild-type human kinases. A selectivity score $\left(S_{10}\right)$ for each compound is included in Table 1, representative of the percentage of kinases that exhibit binding with a percent of control $(\mathrm{PoC})<10$ at $1 \mu \mathrm{M}$. A final column is included that converts this $S_{10}(1 \mu \mathrm{M})$ value into the number of kinases bound with a PoC $<10$ in the DiscoverX panel. Figure S1 details the specific wild-type kinases that bound with a PoC $<10$ at $1 \mu \mathrm{M}$ in the DiscoverX scanMAX panel.

This more comprehensive analysis of selectivity surfaced many findings. We learned that trends within our smaller curated enzymatic kinase panel were generally maintained in this larger profiling effort. Compounds that were the most selective in the Eurofins enzymatic panel were largely those that demonstrated the most favorable selectivity profile in the DiscoverX scanMAX screening. We identified a number of pyrimidine-based kinase inhibitors with useful selectivity. To provide some context on a useful selectivity threshold for tool compounds, we include kinase inhibitors with an $S_{10}(1 \mu \mathrm{M})<0.04$ in our kinase chemogenomic set (KCGS) since they are the compounds that when screened can be more easily used to correlate phenotype with kinase target. ${ }^{31,32} 14$ of 21 , or $67 \%$, of our novel inhibitors were found to be KCGS eligible based on their selectivity scores. We confirmed that kinases potently inhibited in the smaller enzymatic panel were also inhibited in the DiscoverX profiling and identified additional kinases that were differentially inhibited by certain analogs, providing fodder for future projects.

Taken together, our NanoBRET profiling (Table 2) and kinomewide screening (Table 1) enabled us to confirm that GSK8612 is the most potent in cells, selective $\left(S_{10}(1 \mu \mathrm{M})=0.02\right)$, and the most useful TBK1 inhibitor from all that we tested. We were not able to improve upon the activity of this published compound through our 
synthetic efforts. Next, of the DRAK1 active compounds in the NanoBRET assay, only 4 was selective enough to be considered a valuable tool molecule. Given its $S_{10}(1 \mu \mathrm{M})=0.027$ and submicromolar IC $_{50}$ value in the DRAK1 NanoBRET assay, compound 4 was nominated as a dark kinase tool that can be used to illuminate the function of DRAK1. Information for compound $\mathbf{4}$ has been posted on the Dark Kinase Knowledgebase. ${ }^{33}$ Finally, selectivity profiling shows that all compounds with sub-micromolar $\mathrm{IC}_{50}$ values in the MARK3/4 NanoBRET assays require further optimization to reduce the number of off-target kinases that are potently inhibited in addition to MARK3/4 $\left(S_{10}(1 \mu \mathrm{M})=0.067-0.233\right)$. Efforts are ongoing to improve the selectivity of analogs we identified as cellactive in the MARK3/4 NanoBRET assays.

Table 3. Combined enzymatic data

\begin{tabular}{|c|c|c|c|}
\hline Cmpd & $\begin{array}{l}\text { Potently } \\
\text { active }^{[a]}\end{array}$ & $\begin{array}{l}\text { Moderately } \\
\text { active }^{[\mathbf{b}]}\end{array}$ & $\begin{array}{l}\text { Weakly } \\
\text { active }^{[c]}\end{array}$ \\
\hline 15 & & $\begin{array}{c}\text { MYLK2 }=479 \\
\text { nM }\end{array}$ & DRAK2: $91 \%$ \\
\hline 8 & & & $\begin{array}{c}\text { MKNK2 = } 2866 \\
\text { nM, DRAK2: } \\
60 \%, \text { YANK2 } \\
>10000 \mathrm{nM}\end{array}$ \\
\hline 12 & & $\mathrm{CSF} 1 \mathrm{R}=233 \mathrm{nM}$ & \\
\hline 16 & $\begin{array}{c}\text { TYK2 }=33 \\
\mathrm{nM}\end{array}$ & $\mathrm{CSF} 1 \mathrm{R}=305 \mathrm{nM}$ & JAK2: $62 \%$ \\
\hline 21 & & $\begin{array}{l}\text { TBK1 }=128 \mathrm{nM} \\
\mathrm{TRKA}=477 \mathrm{nM}\end{array}$ & $\begin{array}{c}\text { BMPR2 = } 2918 \\
\text { nM, AURKB: } \\
61 \% \text {, JAK2: } 107 \%\end{array}$ \\
\hline 3 & $\begin{array}{c}\text { LRRK2 }=89 \\
\mathrm{nM}\end{array}$ & & $\begin{array}{c}\text { DRAK2: } 59 \%, \\
\text { NIM1 = 4398 } \\
\text { nM, MYLK2 = } \\
1119 \text { nM }\end{array}$ \\
\hline 5 & & $\mathrm{TBK} 1=149 \mathrm{nM}$ & $\mathrm{IKK} \varepsilon=1199 \mathrm{nM}$ \\
\hline 11 & & $\begin{array}{l}\mathrm{TBK} 1=187 \mathrm{nM} \\
\mathrm{TRKA}=153 \mathrm{nM}\end{array}$ & $\begin{array}{c}\text { JAK2: } 87 \%, \text { IKK } \\
=1314 \mathrm{nM} \\
\text { AURKB: } 51 \%\end{array}$ \\
\hline 17 & & $\begin{array}{c}\text { DRAK } 1=325 \\
\mathrm{nM}, \mathrm{DRAK} 2= \\
161 \mathrm{nM}, \mathrm{AAK} 1= \\
390 \mathrm{nM}, \mathrm{SIK} 2= \\
481 \mathrm{nM}\end{array}$ & $\begin{array}{c}\text { MKNK2 = } 769 \\
\text { nM, TYK2 = } 720 \\
\text { nM, JAK2 } \\
>10000 \mathrm{nM}, \\
\text { BMP2K: } 56 \%\end{array}$ \\
\hline 19 & $\begin{array}{c}\mathrm{CSF} 1 \mathrm{R}=91 \\
\mathrm{nM}\end{array}$ & $\mathrm{TYK} 2=276 \mathrm{nM}$ & $\begin{array}{c}\text { JAK2: 54\%, } \\
\text { ERBB2 >10000 } \\
\text { nM, TBK1 = } \\
2737 \mathrm{nM}\end{array}$ \\
\hline GSK8612 & $\begin{array}{c}\mathrm{TBK} 1=37 \\
\mathrm{nM}\end{array}$ & $\begin{array}{c}\text { LRRK2 = } 159 \\
\text { nM, MAP2K5: } \\
11 \%, \text { CSF1R = } \\
264 \mathrm{nM}\end{array}$ & $\begin{array}{c}\mathrm{IKK} \varepsilon=552 \mathrm{nM}, \\
\mathrm{DAPK} 3>10000, \\
\mathrm{NUAK} 2=1151 \\
\mathrm{nM}, \mathrm{ULK} 3=946 \\
\mathrm{nM}, \mathrm{MKNK} 2= \\
1369 \mathrm{nM}\end{array}$ \\
\hline 20 & AURKB: 5\% & $\begin{array}{c}\text { NUAK } 1=176 \\
\mathrm{nM}, \mathrm{SIK} 2=185 \\
\mathrm{nM}\end{array}$ & $\begin{array}{c}\text { BMP2K: 58\%, } \\
\text { DRAK1: 78\%, } \\
\text { DRAK2: 65\%, } \\
\text { JAK2: } 81 \%, \\
\text { ACVR1 = 537 } \\
\text { nM, BMPR1B = } \\
9028 \mathrm{nM}\end{array}$ \\
\hline 4 & $\begin{array}{c}\text { LRRK2 = } 19 \\
\mathrm{nM}, \mathrm{DRAK} 2= \\
62 \mathrm{nM}\end{array}$ & $\begin{array}{c}\text { IKK } \varepsilon=216 \mathrm{nM} \\
\text { DRAK1 = 202 } \\
\text { nM, ULK3 = } 343 \\
\text { nM, MKNK2 = }\end{array}$ & $\begin{array}{c}\text { ULK2 = } 1742 \\
\text { nM, ULK1: } 58 \%\end{array}$ \\
\hline
\end{tabular}

\begin{tabular}{|c|c|c|c|}
\hline & \multicolumn{3}{|c|}{$\begin{array}{c}380 \mathrm{nM}, \mathrm{TBK} 1= \\
192 \mathrm{nM}, \\
\text { MAP2K5: } 12 \%\end{array}$} \\
\hline 13 & $\begin{array}{c}\text { AURKB: } 6 \%, \\
\text { BMP2K }=40 \\
\text { nM, AAK1 }= \\
74 \text { nM, TYK2 } \\
=48 \text { nM, } \\
\text { STK16 = } 82 \\
\text { nM }\end{array}$ & $\begin{array}{l}\text { TBK1 }=192 \mathrm{nM}, \\
\text { JAK2: } 12 \%, \\
\text { BMPR2 }=488 \\
\text { nM, TRKA }=283 \\
\text { nM, NUAK1 }= \\
317 \mathrm{nM}\end{array}$ & $\begin{array}{c}\text { NUAK2 }=900 \\
\text { nM, CSNK2A2 = } \\
2269 \mathrm{nM}, \\
\text { PIP5K1A }>10000 \\
\text { nM, MKNK2 = } \\
1009 \mathrm{nM}\end{array}$ \\
\hline 6 & $\begin{array}{c}\text { TBK1 = 66 } \\
\text { nM, JAK2: } \\
3 \%, \text { BMP2K }= \\
38 \text { nM, STK16 } \\
=88 \mathrm{nM}, \\
\text { TYK2 = 67 } \\
\text { nM, AURKB: } \\
\text { 7\%, AAK1 = } \\
80 \mathrm{nM}\end{array}$ & $\begin{array}{c}\mathrm{CSF} 1 \mathrm{R}=192 \\
\mathrm{nM}, \mathrm{TRKA}=158 \\
\mathrm{nM}, \mathrm{NUAK} 1= \\
171 \mathrm{nM}\end{array}$ & $\begin{array}{c}\text { PRP4 >10000 } \\
\text { nM, PIP5K1A } \\
\text { >10000 nM, } \\
\text { CSNK2A2 = } \\
2304 \mathrm{nM}, \\
\text { CSNK2A1 } \\
\text { >10000 nM, } \\
\text { ULK3 = } 1371 \mathrm{nM}\end{array}$ \\
\hline $\begin{array}{l}{ }^{a} \text { Potently } \\
{ }^{b} \text { Moderat } \\
1 \text { ). 'Weak } \\
\text { IC } 50 \text { value }\end{array}$ & $\begin{array}{l}\mathrm{IC}_{50} \text { value }<1 \\
\text { ve: } \mathrm{IC}_{50} \text { value } 2 \\
\text { : } \mathrm{IC}_{50} \text { value }>50 \\
\text { mined in duplic }\end{array}$ & $\begin{array}{l}\mathrm{AM} \text { or }<10 \% \text { con } \\
500 \mathrm{nM} \text { or } 10-499 \\
\mathrm{M} \text { or }>49 \% \text { contro }\end{array}$ & $\begin{array}{l}\text { at } 1 \mu \mathrm{M} \text { (Table } 1) \\
\text { ontrol at } 1 \mu \mathrm{M}(\mathrm{Table} \\
1 \mu \mathrm{M} \text { (Table } 1) .{ }^{a, b, c} \mathrm{Al}\end{array}$ \\
\hline
\end{tabular}

Orthogonal Validation of scanMAX Results. The scanMAX assay identifies potential targets for our compounds across the kinome. We chose to follow up and validate the scanMAX kinase binding results by further testing of actives in enzyme inhibition assays. Our choice of kinases for follow-up varied depending on the selectivity of the compound in question, as measured by $S_{10}(1 \mu \mathrm{M})$. Highly selective compounds have the potential to be chemical probe candidates, and, as such, we chose to execute thorough enzyme profiling to validate or invalidate potential off-targets. Thus, for the 5 compounds in our library with an $S_{10}(1 \mu \mathrm{M})<0.002(\mathbf{1 5}, \mathbf{8}, 12,16$, and 21 ) we followed-up on all kinases inhibited $>65 \%$ at $1 \mu \mathrm{M}$ in the scanMAX platform and/or inhibited $>50 \%$ in our initial custom enzymatic profiling panel at Eurofins (Table 1). One exception to this was exclusion of AURKA follow-up for 21. For the 6 compounds in our library with an $S_{10}(1 \mu \mathrm{M})=0.005-0.02(\mathbf{3}, \mathbf{5}, \mathbf{1 1}, \mathbf{1 7}, \mathbf{1 9}$, and GSK8612), we carried out enzymatic assays on all kinases inhibited $>80 \%$ at $1 \mu \mathrm{M}$ in the scanMAX platform and/or inhibited $>50 \%$ in our initial enzymatic profiling at Eurofins (Table 1). Given our interest in identifying chemical leads, a few additional understudied kinases inhibited $>65 \%$ at $1 \mu \mathrm{M}$ in the scanMAX platform by these 6 compounds were also selected for follow-up. Lastly, for a final 4 compounds $\left(\mathbf{2 0}, \mathbf{4}, \mathbf{1 3}\right.$, and 6) with $S_{10}(1 \mu \mathrm{M})=0.022-0.047$, we selected only certain kinases inhibited $>80 \%$ at $1 \mu \mathrm{M}$ in the scan MAX platform and/or inhibited $>50 \%$ in our initial profiling at Eurofins (Table 1) for targeted follow-up, with a bias toward kinases that were frequently inhibited by other analogs in the series as well as understudied kinases of interest. All follow-up enzymatic assays were executed at the $\mathrm{K}_{\mathrm{m}}=$ ATP for each respective kinase. Results from these studies combined with the single-concentration enzymatic results from Table 1 are displayed in Table 3 . Compounds in Table 3 are listed in order of their kinome-wide selectivity scores from most (15) to least (6) selective.

In examining the data generated and collected in Table 3 some interesting trends emerge. The most selective compounds $\left(\mathrm{S}_{10}(1\right.$ $\mu \mathrm{M})<0.02: 15,8,12,16$, and 21) that were comprehensively profiled via enzymatic assays potently inhibited $0-1$ kinases (Potently active, Table 3). We classify the kinases potently inhibited by these compounds as more well-studied. With the exception of 17 and GSK8612, the same group of most selective compounds $\left(\mathrm{S}_{10}(1\right.$ $\mu \mathrm{M})<0.02$ ) inhibited 0-2 kinases with moderate potency (Table 3). 
Some less selective compounds (13 and 6) for which we did selective enzymatic follow-up were found to be potent inhibitors of 5-7 kinases, including several from the understudied NAK family (AAK1, BMP2K, STK16). ${ }^{17}$ Several of the pyrimidines tested were found to demonstrate $\mathrm{IC}_{50}$ values of $200-500 \mathrm{nM}$ or inhibition equal to $10-49 \%$ control at $1 \mu \mathrm{M}$ for understudied kinases. Given their kinome-wide selectivity scores and modest potency, these compounds represent good chemical leads for the development of chemical tools to study these poorly characterized kinases. Many kinases were assigned the weakly active designation based on weak potency in the respective enzymatic assays. In some cases, such as with compounds 5 and 13, two kinases that share high structural homology were inhibited with differential potencies. For compound 5, there is an 8-fold difference in potency for TBK1 and IKKe, and for compound 13 there is a nearly 3 -fold difference between NUAK1 and NUAK2.

Importantly, we see that the compounds with sub-micromolar $\mathrm{IC}_{50}$ values in the respective NanoBRET assays corresponded with enzymatic inhibition $\mathrm{IC}_{50}$ values $<250 \mathrm{nM}$ for GSK8612 (TBK1 = $37 \mathrm{nM})$ and compound 4 (DRAK1 = $202 \mathrm{nM})$. TBK1, LRRK2, DRAK1/2, CSF1R, TYK2, and TRKA were identified as frequently inhibited kinases by our pyrimidine series. This list is comprised of some kinases that pyrimidines are known to potently inhibit (TBK1 and TYK2 $\left.2^{34,35}\right)$ as well as kinases that represent new targets for optimization. Analysis of the compounds that inhibit these kinases could inform next steps in new chemistry to develop specific SAR for these kinases. Before embarking on next synthetic steps, the narrow selectivity profiles of exemplars within our series coupled with potent enzymatic data motivated interrogation of the cell-based activity of some of these compounds in the respective NanoBRET assays.

Table 4. Selected NanoBRET follow-up

\begin{tabular}{|c|c|c|c|c|c|c|}
\hline \multirow[b]{2}{*}{ Cmpd } & \multicolumn{6}{|c|}{ IC $_{50}$ values $(\mathrm{nM})^{[\mathbf{a}]}$} \\
\hline & $\hat{\sum}_{\mathscr{n}}^{\stackrel{n}{N}}$ & $\stackrel{3}{3}$ & 祤 & $\underset{2}{2}$ & $\begin{array}{l}\overrightarrow{3} \\
\text { z } \\
\text { z }\end{array}$ & $\underset{\mathscr{Z}}{\tilde{Z}}$ \\
\hline 3 & & & $>10000$ & & & \\
\hline 6 & 1020 & & & & 7010 & \\
\hline 12 & & $>10000$ & & & & \\
\hline 13 & 3000 & & & & $>10000$ & \\
\hline 15 & & & & 3670 & & \\
\hline 16 & & $>10000$ & & & & $>10000$ \\
\hline 19 & & 5060 & & & & $>10000$ \\
\hline GSK8612 & & $>10000$ & $>10000$ & & & \\
\hline
\end{tabular}

${ }^{a}$ Compounds tested in singlicate $(\mathrm{n}=1)$ in dose-response.

Selective NanoBRET Assay Follow-up. For compounds in Table 3 that inhibited kinases with potency $<500 \mathrm{nM}$ we elected to determine their cellular target engagement via the NanoBRET assay. No more than 2 kinases were evaluated per compound. Several single digit micromolar inhibitors of specific kinases were identified amongst these selective pyrimidine compounds. Table 4 shows that these compounds were most cell-active in the BMP2K NanoBRET assay. We were excited to identify that weaker inhibition of MYLK2 in the enzymatic assay $\left(\mathrm{IC}_{50}\right.$ value $=479 \mathrm{nM}$ ) translated to single digit micromolar activity in the MYLK2 NanoBRET assay. Compound $\mathbf{1 5}$ is the most selective of the compounds that we synthesized (Tables 1 and 3 ) and represents a high-quality chemical starting point for MYLK2 chemical probe development. We also observed that compounds that exhibited potent activity in the LRRK2 enzyme assay ( 3 and GSK8612, IC 50 values $<160 \mathrm{nM}$ ) and in the TYK2 enzyme assay ( 16 and 19, IC $_{50}$ values $<280 \mathrm{nM}$ ) did not have any activity in the respective NanoBRET assays when tested at concentrations up to $10 \mu \mathrm{M}$. The disparity between our enzymatic potencies and NanoBRET IC $_{50}$ values prompted us to further investigate compound properties that might impact cell permeability.

Assessment of Compound Properties. With exceptions, we observed >30-300-fold losses in potency when considering enzymatic versus NanoBRET activities. This was true for NanoBRET values reported both in Tables 2 and 4 . A $<10$-fold loss in potency was only observed in 4 cases: GSK8612 for TBK1, 15 for MYLK2, and $\mathbf{4}$ and $\mathbf{1 7}$ for DRAK1. The overall trend of biochemical activity not translating to cellular potency made us curious about the physicochemical properties of our pyrimidines. To address this, we evaluated the kinetic solubility and permeability (PAMPA) of our library of compounds and included the parent compounds as well (Table 5).

Table 5. Kinetic solubility and PAMPA assay results.

\begin{tabular}{|c|c|c|}
\hline Cmpd & Kinetic solubility $(\mu \mathbf{M})$ & $P_{e}(\mathrm{~cm} / \mathrm{s})$ \\
\hline 3 & 171.0 & $3.89 \mathrm{E}-07$ \\
\hline 4 & 190.1 & $5.08 \mathrm{E}-06$ \\
\hline 5 & 33.2 & $<\mathrm{LOQ}^{[\mathrm{a}]}$ \\
\hline 6 & 4.7 & $<\mathrm{LOQ}^{[\mathrm{a}]}$ \\
\hline 7 & 40.3 & $3.73 \mathrm{E}-06$ \\
\hline 8 & 174.6 & $2.39 \mathrm{E}-06$ \\
\hline 9 & 159.0 & $1.30 \mathrm{E}-06$ \\
\hline 10 & 195.2 & $1.51 \mathrm{E}-06$ \\
\hline 11 & 118.7 & $7.09 \mathrm{E}-07$ \\
\hline 12 & 167.7 & $<\mathrm{LOQ}^{[\mathrm{a}]}$ \\
\hline 13 & 20.0 & $<\mathrm{LOQ}^{[\mathrm{a}]}$ \\
\hline 14 & 173.6 & $5.61 \mathrm{E}-07$ \\
\hline 15 & 176.9 & $6.23 \mathrm{E}-08$ \\
\hline 16 & 147.0 & $<\mathrm{LOQ}^{[\mathrm{a}]}$ \\
\hline 17 & 169.3 & $8.24 \mathrm{E}-08$ \\
\hline 18 & 135.6 & $8.85 \mathrm{E}-07$ \\
\hline 19 & 176.5 & $4.56 \mathrm{E}-07$ \\
\hline 20 & 199.7 & $1.66 \mathrm{E}-07$ \\
\hline 21 & 85.6 & $2.60 \mathrm{E}-06$ \\
\hline 22 & 164.0 & 5.97E-07 \\
\hline MRT67307 & 164.6 & $2.60 \mathrm{E}-06$ \\
\hline BX-912 & 155.5 & $1.39 \mathrm{E}-07$ \\
\hline GSK8612 & 173.1 & $<\mathrm{LOQ}^{[\mathrm{a}]}$ \\
\hline
\end{tabular}

$a^{a}<$ LOQ: Below limit of quantitation.

Results in Table 5 demonstrated that our compounds were generally very soluble. With the exception of $5,6,7,11,13,16,18$, and 21, the measured solubility was estimated to be greater than $75 \%$ of the dose concentration and thus the actual solubility may be higher than Table 5 reflects. As nearly all compounds demonstrated solubility $>10 \mu \mathrm{M}$, they were not considered poorly soluble, and this was eliminated from consideration as driving their poor cellular potency. The permeability data, however, was a bit more varied for 
this pyrimidine library. Six compounds $(5,6,12,13,16$, and GSK8612) were below the limit of quantitation (LOQ) and/or precipitated in the assay media, making it impossible to determine their permeability. Several of these compounds were amongst the analogs with the lowest kinetic solubility concentrations as well. For reference, $\mathrm{P}_{\mathrm{e}}$ (permeability coefficient) values $<1.50 \mathrm{E}-06 \mathrm{~cm} / \mathrm{s}$ correlate with human fraction absorbed $<80 \%$ and is a generally accepted cutoff for low permeability. In addition to the compounds already mentioned that were below the LOQ this cutoff adds the majority of our library as well as some parent compounds to a low permeability category: 3, 9, 11, 14, 15, 17-20, 22, and BX-912.

If we start to consider which structural elements could be compromising the solubility and/or permeability of our compounds, some trends emerge. The sulfonamide side chain is present in the majority of the least soluble compounds $(\mathbf{5}, \mathbf{6}, \mathbf{1 1}, \mathbf{1 3}$, 16, and 21) and all poorly permeable compounds $(5,6,12,13,16$, and GSK8612). As compounds with suboptimal solubility (7) or poor permeability (GSK8612) still proved active in our NanoBRET assays, just looking at half of the data is not sufficient. None of the compounds with both problematic solubility and permeability $(\mathbf{5}, \mathbf{6}$, 13, and 16) were active in our NanoBRET assays, leading us to conclude that these two factors together point to compounds that are poorly cell permeable. Since the majority of compounds did not fall into this final category, consideration of physicochemical properties did not explain our cell-based results.

It is worth noting for compounds/kinases where enzymatic data has been published, the control compounds used in the NanoBRET assays can be considered as a benchmark. For CSF1R, dasatinib has a published enzymatic $\mathrm{IC}_{50}=0.57 \mathrm{nM}$ and we determined its NanoBRET IC $_{50}$ to be $18.3 \mathrm{nM}$. For NUAK1, BX-795 has a published $\mathrm{IC}_{50}=5 \mathrm{nM}$ and we determined its NanoBRET IC $\mathrm{I}_{50}$ to be 187 nM. $^{19}$ In both cases, single-digit or sub-nanomolar enzymatic $\mathrm{IC}_{50}$ values translated to sub-micromolar NanoBRET IC $_{50}$ values and a $\sim 34$-fold loss in potency was observed when moving to the cellbased assay. While not universal, it appears that for this set of compounds and kinase targets exceptional enzymatic potency is key to achieving cellular potency to overcome the more than 30 -fold drop-off in cellular potency.

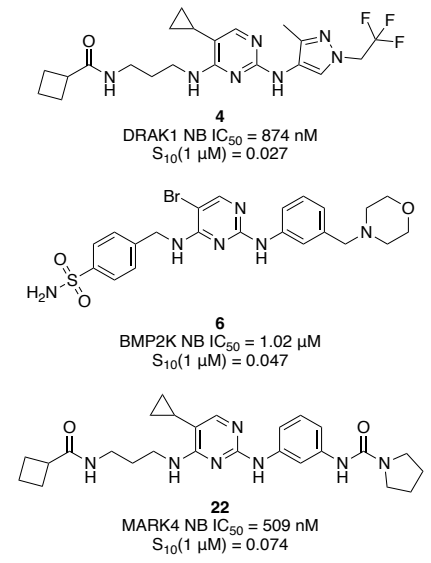

Figure 3. Promising chemical leads for understudied kinases.

\section{CONCLUSIONS}

In summary, we provide details related to the synthesis and extensive biological evaluation of a library of pyrimidines. We have shown that selectivity can be built into the pyrimidine scaffold through medicinal chemistry optimization. Several cell-active compounds were discovered that exhibit sub-micromolar NanoBRET cellular target engagement $\mathrm{IC}_{50}$ values against kinases including TBK1, DRAK1, MARK3, and MARK4. Three of these kinases (DRAK1, MARK3, and MARK4) are understudied, IDG kinases that are in need of high-quality chemical tools to be able to characterize their function. Examples of compounds with sub-micromolar activities for understudied kinases and modest kinome-wide selectivity are included in Figure 3. These pyrimidines represent high-quality chemical starting points in our campaign to identify chemical probes to enable elucidation of the biological function(s) of lesser studied kinases. Results here reiterate the need to employ orthogonal biochemical and cell-based assays in order to more fully understand the actual selectivity and potency of kinase inhibitors. The methods described herein offer a path for others to identify and develop highquality inhibitors for understudied kinases to facilitate illumination of the entire druggable kinome.

\section{EXPERIMENTAL SECTION}

Chemistry. General Information. Reagents were purchased from commercial suppliers and used without further characterization or purification. Temperatures are given in degrees Celsius $\left({ }^{\circ} \mathrm{C}\right)$; unless otherwise stated, operations were carried out at room or ambient temperature (r.t.), typically around $25^{\circ} \mathrm{C}$; evaporation of solvent was carried out using a rotary evaporator under reduced pressure with a bath temperature not exceeding 60 ${ }^{\circ} \mathrm{C}$; thin layer chromatography (TLC) was used to follow the course of reactions; intermediates and products exhibited satisfactory ${ }^{1} \mathrm{H}$ NMR and/or microanalytical data; and the following conventional abbreviations are also used: equivalents (eq), $\mathrm{mL}$ (milliliters), mmol (millimoles), g (grams), mg (milligrams), min (minutes), and $\mathrm{h}$ (hours). Reactions were carried out under a blanket of nitrogen unless otherwise stated. Compounds were visualized using a UV (ultraviolet) lamp (254 nM). ${ }^{1} \mathrm{H}$ and ${ }^{13} \mathrm{C}$ NMR spectra were collected in DMSO- $d_{6}$, acetonitrile- $d_{4}$, chloroform- $d$, or methanol- $d_{4}$ and recorded on Varian Inova 400 Megahertz (MHz), Bruker DRX $500 \mathrm{MHz}$, Bruker Avance III $400 \mathrm{MHz}$, Varian VNMRS $500 \mathrm{MHz}$, or Agilent ProPulse $600 \mathrm{MHz}$ spectrometers, noting the magnet strength in all cases. Peak positions are given in parts per million (ppm) and calibrated based upon the shift of the indicated solvent; coupling constants ( $J$ values) are expressed in hertz $(\mathrm{Hz})$; multiplicities are reported as follows: singlet (s), doublet (d), doublet of doublets (dd), doublet of doublet of doublets (ddd), triplet $(\mathrm{t})$, triplet of doublets $(\mathrm{td})$, triplet of triplet of doublets $(\mathrm{ttd})$, doublet of triplets $(\mathrm{dt})$, quartet $(\mathrm{q})$, doublet of quartets $(\mathrm{dq})$, quartet of doublets (qd), pentet $(\mathrm{p})$, pentet of doublets $(\mathrm{pd})$, heptet $(\mathrm{h})$, and multiplet $(\mathrm{m})$. Purity was assessed via LC-MS using an Agilent mass spectrometer (column: Agilent Poroshell 120 SB-C18, $4.6 \mathrm{~mm}$ X 30 mm, $2.7 \mu \mathrm{m}$ with UHPLC Guard Infinity Lab Poroshell 120 SB-C18, $4.6 \mathrm{~mm}$ X $5 \mathrm{~mm}, 2.7 \mu \mathrm{m})$.

General Procedure for the Synthesis of Compound 2: Procedure A. To a solution of compound 1 (1 eq) in ethanol (10$20 \mathrm{~mL}$ ) were added dropwise DIPEA $(2 \mathrm{~mL})$ and amine 1 (1 eq) at $-10^{\circ} \mathrm{C}$. The resulting mixture was heated to r.t. then stirred at $50^{\circ} \mathrm{C}$ for $16 \mathrm{~h}$. Solvent was next evaporated from the reaction mixture and to the resulting material was added water $(30 \mathrm{~mL})$. The obtained precipitate was filtered, washed with water, isopropanol, and hexane, and dried under vacuum at $50^{\circ} \mathrm{C}$ to give compounds $\mathbf{2 a - 2} \mathbf{g}$ (amount, yield, purity), which were used in the next step without further purification. 
N-(3-((2-chloropyrimidin-4-

yl)amino)propyl)cyclobutanecarboxamide (2a): $330 \mathrm{mg}, 50 \%$ yield, $95 \%$ purity by LC-MS.

N-(3-((5-bromo-2-chloropyrimidin-4-

yl)amino)propyl)cyclobutanecarboxamide (2b): $2.20 \mathrm{~g}, 50 \%$ yield, $95 \%$ purity by LC-MS.

$\mathrm{N}$-(3-((2-chloro-5-cyclopropylpyrimidin-4-

yl)amino)propyl) cyclobutanecarboxamide (2c): $570 \mathrm{mg}, 67 \%$ yield, $95 \%$ purity by LC-MS.

4-(((5-bromo-2-chloropyrimidin-4-

yl)amino)methyl)benzenesulfonamide (2d): $6.40 \mathrm{~g}$, $55 \%$ yield, 95\% purity by LC-MS.

4-(((2-chloro-5-cyclopropylpyrimidin-4-

yl)amino)methyl)benzenesulfonamide (2e): $850 \mathrm{mg}$, 50\% yield, 95\% purity by LC-MS.

N-(2-(1H-imidazol-4-yl)ethyl)-5-bromo-2-

chloropyrimidin-4-amine (2f): $2.50 \mathrm{~g}$, $25 \%$ yield, $95 \%$ purity by LC-MS.

$\mathrm{N}$-(2-(1H-imidazol-4-yl)ethyl)-2-chloro-5-

cyclopropylpyrimidin-4-amine (2g): $420 \mathrm{mg}, 50 \%$ yield, $95 \%$ purity by LC-MS.

General Procedure for the Synthesis of Compounds 3-11, 13, 14, 17, 18, 21, 22, and GSK8612: Procedure B. To a solution of compound 2 ( $1 \mathrm{eq}$ ) and amine 2 (1 eq) in butanol (2-5mL) was added Dioxane $\times \mathrm{HCl}(10 \% \mathrm{w} / \mathrm{w})(0.5-2 \mathrm{~mL})$ and the resulting mixture was stirred at $80^{\circ} \mathrm{C}$ for $16 \mathrm{~h}$. The reaction mixture was next neutralized with aqueous ammonia and concentrated under vacuum. The resulting material was purified by preparative HPLC (2-7 $\mathrm{min}, 35-70 \%$ methanol (0.1\% ammonium hydroxide), 30 $\mathrm{mL} / \mathrm{min}$; column: YMC-ACTUS TRIART C18, $20 \mathrm{~mm} \mathrm{X} 100 \mathrm{~mm}$, $5 \mu \mathrm{m})$ to give final compounds 3-11, 13, 14, 17, 18, 21, 22, and GSK8612 (amount, yield).

$\mathrm{N}^{4}$-(2-(1H-imidazol-4-yl)ethyl)-5-cyclopropyl- $\mathrm{N}^{2}$-(3methyl-1-(2,2,2-trifluoroethyl)-1H-pyrazol-4-yl)pyrimidine2,4-diamine (3): $71.0 \mathrm{mg}, 36 \%$ yield. ${ }^{1} \mathrm{H}$ NMR (400 MHz, DMSO$\left.d_{6}\right) \delta 11.86(\mathrm{~s}, 1 \mathrm{H}), 8.11(\mathrm{~s}, 2 \mathrm{H}), 7.56(\mathrm{~s}, 2 \mathrm{H}), 6.84(\mathrm{~d}, J=16.5 \mathrm{~Hz}$, $2 \mathrm{H}), 5.02-4.91(\mathrm{~m}, 2 \mathrm{H}), 3.63(\mathrm{q}, J=6.8 \mathrm{~Hz}, 2 \mathrm{H}), 2.81(\mathrm{t}, J=7.4 \mathrm{~Hz}$, $2 \mathrm{H}), 2.16(\mathrm{~s}, 3 \mathrm{H}), 1.41(\mathrm{td}, J=10.7,8.6,5.9 \mathrm{~Hz}, 1 \mathrm{H}), 0.78(\mathrm{~d}, J=8.0$ $\mathrm{Hz}, 2 \mathrm{H}), 0.40(\mathrm{t}, J=5.1 \mathrm{~Hz}, 2 \mathrm{H}) .{ }^{13} \mathrm{C}$ NMR $(151 \mathrm{MHz}$, Acetonitrile$\left.d_{3}\right) \delta 160.51,156.33,150.93,138.16,134.55,132.59,121.60$ (q, $J=$ $280.0 \mathrm{~Hz}), 120.39,120.11,113.02,107.40,49.73(\mathrm{q}, J=33.9 \mathrm{~Hz})$, $38.56,24.68,8.17,5.05,1.84$. HPLC purity: $95.0 \%$. HRMS (ESI) $\left([\mathrm{M}+\mathrm{H}]^{+}\right)$Calcd. for $\mathrm{C}_{18} \mathrm{H}_{22} \mathrm{~F}_{3} \mathrm{~N}_{8}: 407.1920$, found: 407.1918 .

N-(3-((5-cyclopropyl-2-((3-methyl-1-(2,2,2-trifluoroethyl)$1 H$-pyrazol-4-yl)amino)pyrimidin-4-

yl)amino)propyl)cyclobutanecarboxamide (4): $57.0 \mathrm{mg}, 11 \%$ yield. ${ }^{1} \mathrm{H}$ NMR (400 MHz, Chloroform-d) $\delta 8.01(\mathrm{~s}, 1 \mathrm{H}), 7.70$ (s, $1 \mathrm{H}), 6.21(\mathrm{~s}, 1 \mathrm{H}), 5.94(\mathrm{~s}, 1 \mathrm{H}), 5.59(\mathrm{~s}, 1 \mathrm{H}), 4.62(\mathrm{q}, J=8.5 \mathrm{~Hz}$, $2 \mathrm{H}), 3.53(\mathrm{q}, J=5.9 \mathrm{~Hz}, 2 \mathrm{H}), 3.36(\mathrm{q}, J=6.3 \mathrm{~Hz}, 2 \mathrm{H}), 2.96$ (p, $J=$ $8.2 \mathrm{~Hz}, 1 \mathrm{H}), 2.31-2.19(\mathrm{~m}, 5 \mathrm{H}), 2.18-2.10(\mathrm{~m}, 2 \mathrm{H}), 2.03-1.82(\mathrm{~m}$, $2 \mathrm{H}), 1.77$ (p, $J=6.7 \mathrm{~Hz}, 2 \mathrm{H}), 1.51-1.40(\mathrm{~m}, 1 \mathrm{H}), 1.25(\mathrm{~s}, 1 \mathrm{H}), 0.91$ $(\mathrm{dq}, J=5.7,3.9 \mathrm{~Hz}, 2 \mathrm{H}), 0.53-0.45(\mathrm{~m}, 2 \mathrm{H}) .{ }^{13} \mathrm{C} \mathrm{NMR}(101 \mathrm{MHz}$, Chloroform-d) $\delta 175.72,162.75,157.86,152.71,140.54,123.13(\mathrm{q}$, $J=280 \mathrm{~Hz}$ ), 122.38, 121.92, 110.04, 52.97 (q, $J=34.7 \mathrm{~Hz}), 39.91$, $37.24,36.04,29.84,25.43,18.09,10.99,7.41,4.56$. HPLC purity: $100 \%$. HRMS (ESI) $\left([\mathrm{M}+\mathrm{H}]^{+}\right)$Calcd. for $\mathrm{C}_{21} \mathrm{H}_{29} \mathrm{~F}_{3} \mathrm{~N}_{7} \mathrm{O}: 452.2386$, found: 452.2385 . 4-(((5-cyclopropyl-2-((3-methyl-1-(2,2,2-trifluoroethyl)1H-pyrazol-4-yl)amino)pyrimidin-4-

yl)amino)methyl)benzenesulfonamide (5): $74.0 \mathrm{mg}, 15 \%$ yield. ${ }^{1} \mathrm{H}$ NMR (400 MHz, DMSO- $\left.d_{6}\right) \delta 8.01(\mathrm{~s}, 1 \mathrm{H}), 7.79-7.70(\mathrm{~m}, 3 \mathrm{H})$, 7.59 (s, 1H), 7.46 (d, J = 8.0 Hz, 2H), 7.38-7.33 (m, 1H), 7.26 (s, $2 \mathrm{H}), 4.87(\mathrm{q}, J=9.2 \mathrm{~Hz}, 2 \mathrm{H}), 4.68(\mathrm{~d}, J=6.1 \mathrm{~Hz}, 2 \mathrm{H}), 2.08(\mathrm{~s}, 3 \mathrm{H})$, $1.52(\mathrm{~s}, 1 \mathrm{H}), 0.83(\mathrm{~d}, J=8.0 \mathrm{~Hz}, 2 \mathrm{H}), 0.48(\mathrm{~d}, J=5.0 \mathrm{~Hz}, 2 \mathrm{H}) .{ }^{13} \mathrm{C}$ NMR $\left(151 \mathrm{MHz}\right.$, Acetonitrile- $\left.d_{3}\right) \delta 160.37,156.47,151.51,143.05$, $139.49,138.98,125.27,123.81,123.0(\mathrm{q}, J=279 \mathrm{~Hz}), 120.72$, $119.89,107.57,49.90(\mathrm{q}, J=34.0 \mathrm{~Hz}), 41.03,8.12,5.08,1.98$. HPLC purity: $100 \%$. HRMS (ESI) $\left([\mathrm{M}+\mathrm{H}]^{+}\right)$Calcd. for $\mathrm{C}_{20} \mathrm{H}_{23} \mathrm{~F}_{3} \mathrm{~N}_{7} \mathrm{O}_{2} \mathrm{~S}$ : 482.1588, found: 482.1582 .

4-(((5-bromo-2- $((3-$

(morpholinomethyl)phenyl)amino)pyrimidin-4-

yl)amino)methyl)benzenesulfonamide (6): $128 \mathrm{mg}, 24 \%$ yield. ${ }^{1} \mathrm{H}$ NMR (400 MHz, DMSO- $d_{6}$ ) $\delta 9.19(\mathrm{~s}, 1 \mathrm{H}), 8.06(\mathrm{~s}, 1 \mathrm{H}), 7.73$ $(\mathrm{dd}, J=15.3,7.0 \mathrm{~Hz}, 4 \mathrm{H}), 7.60(\mathrm{~s}, 1 \mathrm{H}), 7.50(\mathrm{~d}, J=8.0 \mathrm{~Hz}, 2 \mathrm{H}), 7.43$ $(\mathrm{d}, J=8.2 \mathrm{~Hz}, 1 \mathrm{H}), 7.26(\mathrm{~s}, 2 \mathrm{H}), 7.10(\mathrm{t}, J=7.8 \mathrm{~Hz}, 1 \mathrm{H}), 6.81(\mathrm{~d}, J$ $=7.4 \mathrm{~Hz}, 1 \mathrm{H}), 4.70(\mathrm{~d}, J=6.1 \mathrm{~Hz}, 2 \mathrm{H}), 3.52(\mathrm{~d}, J=4.8 \mathrm{~Hz}, 4 \mathrm{H}), 3.17$ (d, $J=5.2 \mathrm{~Hz}, 2 \mathrm{H}), 2.28(\mathrm{~s}, 4 \mathrm{H}) \cdot{ }^{13} \mathrm{C}$ NMR $(126 \mathrm{MHz}$, Acetonitrile$\left.d_{3}\right) \delta 158.62,156.44,145.31,144.49,141.94,140.19,133.48,128.40$, 127.58, 126.11, 122.69, 121.42, 119.70, 93.02, 66.45, 62.66, 60.58, 53.35, 43.67, 24.27. HPLC purity: 98.4\%. HRMS (ESI) $\left([\mathrm{M}+\mathrm{H}]^{+}\right)$ Calcd. for $\mathrm{C}_{22} \mathrm{H}_{26} \mathrm{BrN}_{6} \mathrm{O}_{3} \mathrm{~S}$ : 533.0970, found: 534.11.

N-(3-((5-bromo-2-((3-methyl-1-(2,2,2-trifluoroethyl)-1Hpyrazol-4-yl)amino)pyrimidin-4-

yl)amino)propyl)cyclobutanecarboxamide (7): $83.0 \mathrm{mg}, 17 \%$ yield. ${ }^{1} \mathrm{H}$ NMR (400 MHz, Chloroform-d) $\delta 7.95$ (s, 2H), 6.34 (s, $1 \mathrm{H}), 6.04-5.99(\mathrm{~m}, 1 \mathrm{H}), 5.58-5.53(\mathrm{~m}, 1 \mathrm{H}), 4.64(\mathrm{q}, J=8.5 \mathrm{~Hz}$, $2 \mathrm{H}), 3.49(\mathrm{q}, J=6.2 \mathrm{~Hz}, 2 \mathrm{H}), 3.35(\mathrm{q}, J=6.4 \mathrm{~Hz}, 2 \mathrm{H}), 2.98(\mathrm{p}, J=$ $8.5 \mathrm{~Hz}, 1 \mathrm{H}), 2.33-2.20(\mathrm{~m}, 5 \mathrm{H}), 2.19-2.08(\mathrm{~m}, 2 \mathrm{H}), 2.04-1.80(\mathrm{~m}$, $2 \mathrm{H}), 1.76(\mathrm{p}, J=6.3 \mathrm{~Hz}, 2 \mathrm{H}) .{ }^{13} \mathrm{C}$ NMR $\left(151 \mathrm{MHz}\right.$, Acetonitrile- $\left.d_{3}\right)$ $\delta 173.06,156.65,156.48,153.76,138.90,121.5(\mathrm{q}, J=279.8)$, $120.99,119.51,119.43,49.88(\mathrm{q}, J=34.2 \mathrm{~Hz}), 37.32,35.47,33.62$, 26.93, 22.78, 15.55, 8.19. HPLC purity: 97.8\%. HRMS (ESI) $\left([\mathrm{M}+\mathrm{H}]^{+}\right)$Calcd. for $\mathrm{C}_{18} \mathrm{H}_{24} \mathrm{BrF}_{3} \mathrm{~N}_{7} \mathrm{O}: 490.1178$, found: 490.1176 .

N-(3-((2-((3-methyl-1-(2,2,2-trifluoroethyl)-1H-pyrazol-4yl)amino)pyrimidin-4-yl)amino)-

propyl)cyclobutanecarboxamide (8): $75.0 \mathrm{mg}, 15 \%$ yield. ${ }^{1} \mathrm{H}$ NMR (400 MHz, Chloroform-d) $\delta 7.98(\mathrm{~s}, 1 \mathrm{H}), 7.83(\mathrm{~d}, J=5.9 \mathrm{~Hz}$, $1 \mathrm{H}), 6.33(\mathrm{~s}, 1 \mathrm{H}), 5.82(\mathrm{~d}, J=5.6 \mathrm{~Hz}, 1 \mathrm{H}), 5.56(\mathrm{~s}, 2 \mathrm{H}), 4.59(\mathrm{q}, J=$ $8.5 \mathrm{~Hz}, 2 \mathrm{H}), 3.41-3.25(\mathrm{~m}, 4 \mathrm{H}), 2.95(\mathrm{p}, J=8.6 \mathrm{~Hz}, 1 \mathrm{H}), 2.31-2.18$ $(\mathrm{m}, 5 \mathrm{H}), 2.13(\mathrm{q}, J=9.1,8.3 \mathrm{~Hz}, 2 \mathrm{H}), 2.01-1.79(\mathrm{~m}, 3 \mathrm{H}), 1.72(\mathrm{p}, J$ $=6.3 \mathrm{~Hz}, 2 \mathrm{H}) \cdot{ }^{13} \mathrm{C} \mathrm{NMR}\left(151 \mathrm{MHz}\right.$, Acetonitrile- $\left.d_{3}\right) \delta 172.67$, 161.10, 157.78, 153.04, 138.64, 125.45, 121.63 (q, $J=280$ ), 120.78, $119.87,118.98,49.87(\mathrm{q}, J=34.0 \mathrm{~Hz}), 37.31,33.92,26.98,22.74$, $15.56,8.19$. HPLC purity: $100 \%$. HRMS (ESI) $\left([\mathrm{M}+\mathrm{H}]^{+}\right)$Calcd. for $\mathrm{C}_{18} \mathrm{H}_{25} \mathrm{~F}_{3} \mathrm{~N}_{7} \mathrm{O}: 412.2073$, found: 412.2069.

$\mathrm{N}^{4}$-(2-(1H-imidazol-4-yl)ethyl)-5-bromo- $\mathrm{N}^{2}$-(3-

(morpholinomethyl)phenyl)pyrimidine-2,4-diamine (9): 190 mg, $11 \%$ yield. ${ }^{1} \mathrm{H}$ NMR $\left(400 \mathrm{MHz}\right.$, DMSO- $\left.d_{6}\right) \delta 11.83(\mathrm{~s}, 1 \mathrm{H}), 9.21$ (s, 1H), $8.01(\mathrm{~s}, 1 \mathrm{H}), 7.75(\mathrm{~s}, 1 \mathrm{H}), 7.63-7.54(\mathrm{~m}, 2 \mathrm{H}), 7.14(\mathrm{t}, J=$ $7.8 \mathrm{~Hz}, 2 \mathrm{H}), 6.83(\mathrm{~d}, J=7.5 \mathrm{~Hz}, 2 \mathrm{H}), 3.68(\mathrm{q}, J=6.9 \mathrm{~Hz}, 2 \mathrm{H}), 3.54$ $(\mathrm{t}, J=4.6 \mathrm{~Hz}, 4 \mathrm{H}), 3.31(\mathrm{~s}, 2 \mathrm{H}), 2.87-2.78(\mathrm{~m}, 2 \mathrm{H}), 2.29(\mathrm{~s}, 4 \mathrm{H})$. ${ }^{13} \mathrm{C}$ NMR (101 MHz, Methanol- $\left.d_{4}\right) \delta 163.42,158.65,158.56$, $155.08,140.37,137.30,134.65,128.08,122.67,120.21,118.15$, $116.24,92.60,66.28,63.13,53.22,40.58,26.34$. HPLC purity: 95.9\%. HRMS (ESI) $\left([\mathrm{M}+\mathrm{H}]^{+}\right)$Calcd. for $\mathrm{C}_{20} \mathrm{H}_{25} \mathrm{BrN}_{7} \mathrm{O}: 458.1304$, found: 458.1300 . 
$\mathrm{N}^{4}$-(2-(1H-imidazol-5-yl)ethyl)-5-bromo- $\mathrm{N}^{2}$-(3-methyl-1(2,2,2-trifluoroethyl)-1H-pyrazol-4-yl)pyrimidine-2,4diamine (10): $325 \mathrm{mg}, 17 \%$ yield. ${ }^{1} \mathrm{H}$ NMR ( $400 \mathrm{MHz}, \mathrm{DMSO}-d_{6}$ ) $\delta 11.84(\mathrm{~s}, 1 \mathrm{H}), 8.55(\mathrm{~s}, 1 \mathrm{H}), 8.09(\mathrm{~s}, 1 \mathrm{H}), 7.95(\mathrm{~s}, 1 \mathrm{H}), 7.55(\mathrm{~s}, 1 \mathrm{H})$, $7.08(\mathrm{~s}, 1 \mathrm{H}), 6.87(\mathrm{~s}, 1 \mathrm{H}), 4.98(\mathrm{~s}, 2 \mathrm{H}), 3.60(\mathrm{q}, J=6.9,6.5 \mathrm{~Hz}, 2 \mathrm{H})$, $2.78(\mathrm{t}, J=7.1 \mathrm{~Hz}, 2 \mathrm{H}), 2.16(\mathrm{~s}, 3 \mathrm{H}) .{ }^{13} \mathrm{C} \mathrm{NMR}(151 \mathrm{MHz}$, Acetonitrile- $\left.d_{3}\right) \delta 156.58,156.46,153.77,144.88,143.51,138.62$, $132.63,121.54$ (q, $J=279.9 \mathrm{~Hz}), 120.99,119.43,117.93,49.74(\mathrm{q}, J$ $=34.1 \mathrm{~Hz}$ ), 38.91, 24.47, 8.21. HPLC purity: 96.6\%. HRMS (ESI) $\left([\mathrm{M}+\mathrm{H}]^{+}\right)$Calcd. for $\mathrm{C}_{15} \mathrm{H}_{17} \mathrm{BrF}_{3} \mathrm{~N}_{8}: 445.0712$, found: 445.0709.

\section{4-(((5-cyclopropyl-2- $((3-$}

(morpholinomethyl)phenyl)amino)pyrimidin-4-

yl)amino)methyl)-benzenesulfonamide (11): $18.0 \mathrm{mg}$, $4 \%$ yield. ${ }^{1} \mathrm{H}$ NMR $\left(400 \mathrm{MHz}\right.$, DMSO- $\left.d_{6}\right) \delta 8.83(\mathrm{~s}, 1 \mathrm{H}), 7.75(\mathrm{~d}, J=8.1 \mathrm{~Hz}$, $2 \mathrm{H}), 7.66(\mathrm{~s}, 2 \mathrm{H}), 7.52(\mathrm{~d}, J=8.0 \mathrm{~Hz}, 2 \mathrm{H}), 7.50-7.42(\mathrm{~m}, 3 \mathrm{H}), 7.25$ $(\mathrm{s}, 2 \mathrm{H}), 7.06(\mathrm{t}, J=7.9 \mathrm{~Hz}, 1 \mathrm{H}), 6.75(\mathrm{~d}, J=7.7 \mathrm{~Hz}, 1 \mathrm{H}), 4.75(\mathrm{~d}, J$ $=5.9 \mathrm{~Hz}, 2 \mathrm{H}), 3.57-3.50(\mathrm{~m}, 5 \mathrm{H}), 3.17(\mathrm{~d}, J=5.5 \mathrm{~Hz}, 2 \mathrm{H}), 2.32-$ $2.25(\mathrm{~m}, 4 \mathrm{H}), 1.61-1.50(\mathrm{~m}, 1 \mathrm{H}), 0.88-0.83(\mathrm{~m}, 2 \mathrm{H}), 0.52(\mathrm{~d}, J=$ $4.7 \mathrm{~Hz}, 2 \mathrm{H}) .{ }^{13} \mathrm{C}$ NMR $\left(101 \mathrm{MHz}\right.$, Methanol- $\left.d_{4}\right) \delta 162.60,158.31$, $152.19,144.97,142.02,140.52,137.00,128.03,127.12,125.89$, 122.35, 120.11, 118.04, 110.30, 66.24, 63.12, 53.13, 43.32, 39.00, 7.14, 3.92. HPLC purity: 100\%. HRMS (ESI) $\left([\mathrm{M}+\mathrm{H}]^{+}\right)$Calcd. for $\mathrm{C}_{25} \mathrm{H}_{31} \mathrm{~N}_{6} \mathrm{O}_{3} \mathrm{~S}: 495.2178$, found: 495.24 .

$\mathrm{N}$-(3-((5-bromo-4-((4-sulfamoylbenzyl)amino)pyrimidin2-yl)amino)phenyl)pyrrolidine-1-carboxamide (13): $383 \mathrm{mg}$, $5 \%$ yield. ${ }^{1} \mathrm{H}$ NMR $\left(500 \mathrm{MHz}\right.$, Methanol- $\left.d_{4}\right) \delta 7.95(\mathrm{~d}, J=2.2 \mathrm{~Hz}$, $1 \mathrm{H}), 7.80(\mathrm{dd}, J=8.4,2.2 \mathrm{~Hz}, 2 \mathrm{H}), 7.71$ (d, $J=2.4 \mathrm{~Hz}, 1 \mathrm{H}), 7.49-$ $7.43(\mathrm{~m}, 2 \mathrm{H}), 7.08(\mathrm{dt}, J=4.6,1.8 \mathrm{~Hz}, 2 \mathrm{H}), 6.95(\mathrm{td}, J=4.3,1.8 \mathrm{~Hz}$, $1 \mathrm{H}), 4.77(\mathrm{~d}, J=2.0 \mathrm{~Hz}, 2 \mathrm{H}), 3.42(\mathrm{dt}, J=6.8,3.5 \mathrm{~Hz}, 4 \mathrm{H}), 1.94(\mathrm{~h}$, $J=2.5 \mathrm{~Hz}, 4 \mathrm{H}) .{ }^{13} \mathrm{C}$ NMR $\left(101 \mathrm{MHz}\right.$, Methanol- $\left.d_{4}\right) \delta 158.61$, $156.19,155.36,153.60,144.23,141.95,140.23,139.55,128.02$, 127.27, 125.75, 114.94, 114.62, 112.77, 92.26, 45.57, 43.56, 25.01. HPLC purity: 92.6\%. HRMS (ESI) $\left([\mathrm{M}+\mathrm{H}]^{+}\right)$Calcd. for $\mathrm{C}_{22} \mathrm{H}_{25} \mathrm{BrN}_{7} \mathrm{O}_{3} \mathrm{~S}: 546.0923$, found: 546.0914 .

$\mathrm{N}^{4}$-(2-(1H-imidazol-4-yl)ethyl)-5-cyclopropyl- $\mathrm{N}^{2}$-(3(morpholinomethyl)phenyl)pyrimidine-2,4-diamine (14): $73.0 \mathrm{mg}, 24 \%$ yield. ${ }^{1} \mathrm{H}$ NMR $\left(400 \mathrm{MHz}, \mathrm{DMSO}-d_{6}\right) \delta 11.82(\mathrm{~s}, 1 \mathrm{H})$, $8.85(\mathrm{~s}, 1 \mathrm{H}), 7.81(\mathrm{~s}, 1 \mathrm{H}), 7.64-7.54(\mathrm{~m}, 3 \mathrm{H}), 7.11(\mathrm{t}, J=7.8 \mathrm{~Hz}$, $1 \mathrm{H}), 6.90-6.81(\mathrm{~m}, 2 \mathrm{H}), 6.77(\mathrm{~d}, J=7.5 \mathrm{~Hz}, 1 \mathrm{H}), 3.69$ (q, $J=6.7$ $\mathrm{Hz}, 2 \mathrm{H}), 3.54(\mathrm{t}, J=4.6 \mathrm{~Hz}, 4 \mathrm{H}), 3.30-3.20(\mathrm{~m}, 1 \mathrm{H}), 3.17(\mathrm{~d}, J=3.9$ $\mathrm{Hz}, 1 \mathrm{H}), 2.85(\mathrm{t}, J=7.2 \mathrm{~Hz}, 2 \mathrm{H}), 2.29(\mathrm{~d}, J=4.8 \mathrm{~Hz}, 4 \mathrm{H}), 1.44(\mathrm{q}, J$ $=4.8,2.9 \mathrm{~Hz}, 1 \mathrm{H}), 0.79(\mathrm{dt}, J=8.3,3.1 \mathrm{~Hz}, 2 \mathrm{H}), 0.51-0.38(\mathrm{~m}, 2 \mathrm{H})$. ${ }^{13} \mathrm{C}$ NMR $\left(151 \mathrm{MHz}\right.$, Acetonitrile- $\left.d_{3}\right) \delta 160.24,156.35,150.71$, $139.02,136.45,132.53,126.05,119.42,116.81,115.42,114.90$, $108.19,64.35,60.97,51.28,38.46,24.40,5.12,1.85$. HPLC purity: $100 \%$. HRMS (ESI) $\left([\mathrm{M}+\mathrm{H}]^{+}\right)$Calcd. for $\mathrm{C}_{23} \mathrm{H}_{30} \mathrm{~N}_{7} \mathrm{O}: 420.2512$, found: 420.2506 .

\section{$\mathrm{N}$-(3-)(4-((3-)}

(cyclobutanecarboxamido)propyl)amino)pyrimidin-2yl)amino)phenyl)pyrrolidine-1-carboxamide (17): $19.0 \mathrm{mg}$, $10 \%$ yield. ${ }^{1} \mathrm{H}$ NMR $(400 \mathrm{MHz}$, Chloroform-d) $\delta 7.94(\mathrm{~s}, 1 \mathrm{H}), 7.82$ (s, 1H), $7.24(\mathrm{~s}, 1 \mathrm{H}), 7.22-7.03(\mathrm{~m}, 3 \mathrm{H}), 6.95(\mathrm{~d}, J=8.2 \mathrm{~Hz}, 1 \mathrm{H})$, $6.13(\mathrm{~s}, 2 \mathrm{H}), 5.80(\mathrm{~d}, J=6.5 \mathrm{~Hz}, 1 \mathrm{H}), 5.56(\mathrm{~s}, 1 \mathrm{H}), 3.41(\mathrm{~m}, 6 \mathrm{H})$, $3.26(\mathrm{~m}, 2 \mathrm{H}), 2.95-2.78(\mathrm{~m}, 1 \mathrm{H}), 2.19(\mathrm{~d}, J=9.8 \mathrm{~Hz}, 2 \mathrm{H}), 2.07-$ $1.89(\mathrm{~m}, 9 \mathrm{H}), 1.68(\mathrm{~d}, J=6.7 \mathrm{~Hz}, 1 \mathrm{H}) .{ }^{13} \mathrm{C}$ NMR $(101 \mathrm{MHz}$, DMSO-d $\left.d_{6}\right) \delta 174.29,162.95,160.25,154.80,154.49,141.70$, $140.83,128.16,113.36,113.15,111.41,98.08,55.31,46.08,39.17$, 36.78, 29.55, 25.47, 25.11, 18.22. HPLC purity: 100\%. HRMS (ESI) $\left([\mathrm{M}+\mathrm{H}]^{+}\right)$Calcd. for $\mathrm{C}_{23} \mathrm{H}_{32} \mathrm{~N}_{7} \mathrm{O}_{2}: 438.2617$, found: 438.2617.
N-(3-)(5-bromo-4-)((3-

(cyclobutanecarboxamido)propyl)amino)pyrimidin-2-

yl)amino)phenyl)pyrrolidine-1-carboxamide (18): $335 \mathrm{mg}$, $13 \%$ yield. ${ }^{1} \mathrm{H}$ NMR ( $400 \mathrm{MHz}$, DMSO- $\left.d_{6}\right) \delta 9.07(\mathrm{~s}, 1 \mathrm{H}), 7.97(\mathrm{~s}$, $1 \mathrm{H}), 7.87(\mathrm{t}, J=2.1 \mathrm{~Hz}, 1 \mathrm{H}), 7.62(\mathrm{t}, J=5.4 \mathrm{~Hz}, 1 \mathrm{H}), 7.25(\mathrm{~d}, J=8.1$ $\mathrm{Hz}, 1 \mathrm{H}), 7.06(\mathrm{t}, J=8.0 \mathrm{~Hz}, 1 \mathrm{H}), 7.00-6.91(\mathrm{~m}, 2 \mathrm{H}), 3.42(\mathrm{q}, J=6.6$ $\mathrm{Hz}, 2 \mathrm{H}), 3.33(\mathrm{~d}, J=6.4 \mathrm{~Hz}, 4 \mathrm{H}), 3.07(\mathrm{q}, J=6.5 \mathrm{~Hz}, 2 \mathrm{H}), 2.93(\mathrm{p}$, $J=8.4 \mathrm{~Hz}, 1 \mathrm{H}), 2.14-2.02(\mathrm{~m}, 4 \mathrm{H}), 1.96(\mathrm{q}, J=9.8 \mathrm{~Hz}, 2 \mathrm{H}), 1.90$ $1.79(\mathrm{~m}, 4 \mathrm{H}), 1.78-1.60(\mathrm{~m}, 3 \mathrm{H}) .{ }^{13} \mathrm{C}$ NMR (101 MHz, Methanol$\left.d_{4}\right) \delta 176.54,158.67,158.61,155.60,155.03,140.53,139.71,128.13$, 114.73, 114.19, 112.40, 92.61, 45.63, 39.47, 37.91, 36.26, 28.86, 25.06, 24.84, 17.58. HPLC purity: 98.1\%. HRMS (ESI) $\left([\mathrm{M}+\mathrm{H}]^{+}\right)$ Calcd. for $\mathrm{C}_{23} \mathrm{H}_{31} \mathrm{BrN}_{7} \mathrm{O}_{2}: 516.1723$, found: 516.20.

\section{$\mathrm{N}$-(3-((5-cyclopropyl-4-)(4-}

sulfamoylbenzyl)amino)pyrimidin-2-

yl)amino)phenyl)pyrrolidine-1-carboxamide (21): $16.0 \mathrm{mg}, 8 \%$ yield. ${ }^{1} \mathrm{H}$ NMR $\left(400 \mathrm{MHz}\right.$, Methanol- $\left.d_{4}\right) \delta 7.80(\mathrm{~d}, J=8.3 \mathrm{~Hz}, 2 \mathrm{H})$, $7.70(\mathrm{t}, J=2.1 \mathrm{~Hz}, 1 \mathrm{H}), 7.47-7.41(\mathrm{~m}, 3 \mathrm{H}), 7.22(\mathrm{t}, J=8.0 \mathrm{~Hz}, 1 \mathrm{H})$, $7.15(\mathrm{dt}, J=8.0,1.5 \mathrm{~Hz}, 1 \mathrm{H}), 6.97(\mathrm{dt}, J=8.0,1.6 \mathrm{~Hz}, 1 \mathrm{H}), 4.82(\mathrm{~s}$, $2 \mathrm{H}), 3.46-3.41(\mathrm{~m}, 4 \mathrm{H}), 1.98-1.92(\mathrm{~m}, 4 \mathrm{H}), 1.57(\mathrm{td}, J=7.9,4.0$ $\mathrm{Hz}, 1 \mathrm{H}), 1.02-0.97$ (m, 2H), 0.61-0.56 (m, 2H). ${ }^{13} \mathrm{C}$ NMR (101 $\mathrm{MHz}$, Methanol- $\left.d_{4}\right) \delta 163.32,155.39,152.73,142.84,142.38$, $140.50,139.89,136.96,128.85,127.60,125.88,117.51,117.11$, $115.24,112.53,45.66,43.99,25.01,23.61,6.92,4.27$. HPLC purity: $100 \%$. HRMS (ESI) $\left([\mathrm{M}+\mathrm{H}]^{+}\right)$Calcd. for $\mathrm{C}_{25} \mathrm{H}_{30} \mathrm{~N}_{7} \mathrm{O}_{3} \mathrm{~S}: 508.2131$, found: 508.23.

$\mathrm{N}$-(3-((4-((3-(cyclobutanecarboxamido)propyl)amino)-5cyclopropylpyrimidin-2-yl)amino)-phenyl)pyrrolidine-1carboxamide (22): $16.0 \mathrm{mg}$, 5\% yield. ${ }^{1} \mathrm{H}$ NMR $(400 \mathrm{MHz}$, Methanol- $\left.d_{4}\right) \delta 7.81(\mathrm{t}, J=2.1 \mathrm{~Hz}, 1 \mathrm{H}), 7.55(\mathrm{~d}, J=1.1 \mathrm{~Hz}, 1 \mathrm{H}), 7.25$ (ddd, $J=8.1,2.2,1.1 \mathrm{~Hz}, 1 \mathrm{H}), 7.15(\mathrm{t}, J=8.1 \mathrm{~Hz}, 1 \mathrm{H}), 6.97$ (ddd, $J$ $=8.0,2.1,1.0 \mathrm{~Hz}, 1 \mathrm{H}), 3.58(\mathrm{t}, J=6.6 \mathrm{~Hz}, 2 \mathrm{H}), 3.47-3.42(\mathrm{~m}, 5 \mathrm{H})$, $3.24(\mathrm{t}, J=6.7 \mathrm{~Hz}, 2 \mathrm{H}), 2.96(\mathrm{pd}, J=8.6,1.0 \mathrm{~Hz}, 1 \mathrm{H}), 2.24-2.14(\mathrm{~m}$, $2 \mathrm{H}), 2.10-2.01(\mathrm{~m}, 2 \mathrm{H}), 1.98-1.93(\mathrm{~m}, 5 \mathrm{H}), 1.84-1.75(\mathrm{~m}, 3 \mathrm{H})$, 1.46 (ttd $J=8.1,5.2,1.1 \mathrm{~Hz}, 1 \mathrm{H}), 0.92-0.87(\mathrm{~m}, 2 \mathrm{H}), 0.49-0.44$ $(\mathrm{m}, 2 \mathrm{H}) .{ }^{13} \mathrm{C}$ NMR $\left(101 \mathrm{MHz}\right.$, Methanol- $\left.d_{4}\right) \delta 176.49,162.67$, 158.29 , 155.62, 151.52, 140.97, 139.70, 128.11, 114.28, 113.88, $112.08,110.40,45.61,39.47,39.00,37.37,36.13,29.14,25.06$, 24.83, 17.57, 7.07, 3.81. HPLC purity: 100\%. HRMS (ESI) $\left([\mathrm{M}+\mathrm{H}]^{+}\right)$Calcd. for $\mathrm{C}_{26} \mathrm{H}_{36} \mathrm{~N}_{7} \mathrm{O}_{2}: 478.2930$, found: 478.33 .

4-(((5-bromo-2-((3-methyl-1-(2,2,2-trifluoroethyl)-1Hpyrazol-4-yl)amino)pyrimidin-4-yl)-

amino)methyl)benzenesulfonamide (GSK8612): $379 \mathrm{mg}, 73 \%$ yield. ${ }^{1} \mathrm{H}$ NMR $\left(400 \mathrm{MHz}\right.$, DMSO- $\left.d_{6}\right) \delta 8.43(\mathrm{~s}, 1 \mathrm{H}), 7.98(\mathrm{~s}, 1 \mathrm{H})$, $7.73(\mathrm{~d}, J=8.0 \mathrm{~Hz}, 3 \mathrm{H}), 7.62-7.53(\mathrm{~m}, 1 \mathrm{H}), 7.41(\mathrm{~s}, 2 \mathrm{H}), 7.27(\mathrm{~s}$, $2 \mathrm{H}), 4.90(\mathrm{q}, J=9.1 \mathrm{~Hz}, 2 \mathrm{H}), 4.61(\mathrm{~s}, 2 \mathrm{H}), 2.08(\mathrm{~s}, 3 \mathrm{H}) .{ }^{13} \mathrm{C} \mathrm{NMR}$ $\left(151 \mathrm{MHz}\right.$, Acetonitrile- $\left.d_{3}\right) \delta 156.82,156.44,154.25,142.15$, $139.72,139.67,125.39,123.87,123.25$ (q, $J=281 \mathrm{~Hz}), 121.58$, 119.20, $49.92(q, J=34.0 \mathrm{~Hz}), 41.30,8.17$. HPLC purity: $100 \%$. HRMS (ESI) $\left([\mathrm{M}+\mathrm{H}]^{+}\right)$Calcd. for $\mathrm{C}_{17} \mathrm{H}_{18} \mathrm{BrF}_{3} \mathrm{~N}_{7} \mathrm{O}_{2} \mathrm{~S}$ : 520.0378, found: 520.0378 .

General Procedure for the Synthesis of Compounds 12, 15, 16, 19, and 20: Procedure C. To a solution of 6, 9, 10, 13, or GSK8612 (1 eq) in methanol $(20 \mathrm{~mL})$ were added 5\% Pd/C $(0.5$ eq) and triethylamine (TEA, $3 \mathrm{eq})$. The resulting mixture was stirred under $\mathrm{H}_{2}$ (hydrogen) atmosphere at r.t. for $16 \mathrm{~h}$. Next the reaction mixture was filtered, and the filtrate was concentrated in vacuo. The crude product was purified via preparative HPLC (2-7 min, 30-55\% acetonitrile, $30 \mathrm{~mL} / \mathrm{min}$; column: SunFire C18, $19 \mathrm{~mm} \mathrm{X} 100 \mathrm{~mm}$, $5 \mu \mathrm{m}$ ) to give 12, 15, 16, 19, and 20 (amount, purity, yield). 
4-(((2-((3-methyl-1-(2,2,2-trifluoroethyl)-1h-pyrazol-4yl)amino)pyrimidin-4-yl)amino)methyl)benzenesulfonamide (12): $108 \mathrm{mg}, 36 \%$ yield. ${ }^{1} \mathrm{H}$ NMR (400 MHz, DMSO- $\left.d_{6}\right) \delta 8.18$ (s, $1 \mathrm{H}), 7.87(\mathrm{~s}, 1 \mathrm{H}), 7.77(\mathrm{dd}, J=8.9,6.9 \mathrm{~Hz}, 3 \mathrm{H}), 7.66(\mathrm{~s}, 1 \mathrm{H}), 7.46$ (d, J = 8.0 Hz, 2H), $7.30(\mathrm{~s}, 2 \mathrm{H}), 5.92(\mathrm{~s}, 1 \mathrm{H}), 4.90(\mathrm{q}, J=9.1 \mathrm{~Hz}$, $2 \mathrm{H}), 4.57$ (s, 2H), 2.11 (s, 3H). ${ }^{13} \mathrm{C}$ NMR (151 MHz, Acetonitrile$\left.d_{3}\right) \delta 161.02,157.98,153.76,142.49,139.69,139.23,125.44,125.24$, $123.88,123.79,121.45$ ( $\mathrm{q}, J=279 \mathrm{~Hz}), 121.16,119.67,94.31,49.96$ (q, $J=34.4 \mathrm{~Hz}$ ), 41.30, 8.11. HPLC purity: 96.6\%. HRMS (ESI) $\left([\mathrm{M}+\mathrm{H}]^{+}\right)$Calcd. for $\mathrm{C}_{17} \mathrm{H}_{19} \mathrm{~F}_{3} \mathrm{~N}_{7} \mathrm{O}_{2} \mathrm{~S}: 442.1273$, found: 442.1270.

$N^{4}$-(2-(1H-imidazol-5-yl)ethyl)- $N^{2}$-(3-methyl-1-(2,2,2trifluoroethyl)-1H-pyrazol-4-yl)pyrimidine-2,4-diamine (15): $86.0 \mathrm{mg}, 10 \%$ yield. ${ }^{1} \mathrm{H}$ NMR (400 MHz, DMSO- $\left.d_{6}\right) \delta 11.81(\mathrm{~s}, 1 \mathrm{H})$, $8.15(\mathrm{~d}, J=35.4 \mathrm{~Hz}, 2 \mathrm{H}), 7.73(\mathrm{~s}, 1 \mathrm{H}), 7.53(\mathrm{~s}, 1 \mathrm{H}), 7.18(\mathrm{~s}, 1 \mathrm{H})$, $6.83(\mathrm{~s}, 1 \mathrm{H}), 5.85(\mathrm{~d}, J=5.8 \mathrm{~Hz}, 1 \mathrm{H}), 4.95(\mathrm{q}, J=9.2 \mathrm{~Hz}, 2 \mathrm{H}), 3.51$ $(\mathrm{s}, 2 \mathrm{H}), 2.75(\mathrm{t}, J=7.5 \mathrm{~Hz}, 2 \mathrm{H}), 2.16(\mathrm{~s}, 3 \mathrm{H}) .{ }^{13} \mathrm{C} \mathrm{NMR}(151 \mathrm{MHz}$, Acetonitrile- $\left.d_{3}\right) \delta 161.05,157.72,153.16,138.57,132.48,122.48$, $121.55(\mathrm{q}, J=280 \mathrm{~Hz}), 120.74,119.80,116.90,114.19,49.77$ (q, $J=$ $32.4 \mathrm{~Hz}$ ), 38.55, 24.75, 8.19. HPLC purity: 100\%. HRMS (ESI) $\left([\mathrm{M}+\mathrm{H}]^{+}\right)$Calcd. for $\mathrm{C}_{15} \mathrm{H}_{18} \mathrm{~F}_{3} \mathrm{~N}_{8}: 367.1607$, found: 367.1596 .

\section{$\mathrm{N}$-(3-((4-((4-sulfamoylbenzyl)amino)pyrimidin-2-}

yl)amino)phenyl)pyrrolidine-1-carboxamide (16): $23.0 \mathrm{mg}, 8 \%$ yield. ${ }^{1} \mathrm{H}$ NMR $\left(400 \mathrm{MHz}, \mathrm{DMSO}-d_{6}\right) \delta 8.83(\mathrm{~s}, 1 \mathrm{H}), 7.94(\mathrm{~s}, 1 \mathrm{H})$, $7.92-7.79(\mathrm{~m}, 3 \mathrm{H}), 7.75(\mathrm{~d}, J=7.9 \mathrm{~Hz}, 3 \mathrm{H}), 7.49(\mathrm{~d}, J=8.0 \mathrm{~Hz}, 2 \mathrm{H})$, $7.27(\mathrm{~s}, 2 \mathrm{H}), 7.19(\mathrm{~s}, 1 \mathrm{H}), 6.99(\mathrm{~d}, J=7.8 \mathrm{~Hz}, 1 \mathrm{H}), 6.93(\mathrm{~s}, 1 \mathrm{H}), 5.98$ (s, 1H), 4.64 (s, 2H), 3.17 (m, 4H), $1.82(\mathrm{~m}, 4 \mathrm{H}) .{ }^{13} \mathrm{C}$ NMR (101 $\left.\mathrm{MHz}, \mathrm{DMSO}-d_{6}\right) \delta 162.86,160.14,155.30,154.46,144.67,142.92$, $141.44,140.84,128.18,127.94,126.07,113.46,113.27,111.51$, 97.85, 46.09, 40.86, 25.46. HPLC purity: 95.0\%. HRMS (ESI) $\left([\mathrm{M}+\mathrm{H}]^{+}\right)$Calcd. for $\mathrm{C}_{22} \mathrm{H}_{26} \mathrm{~N}_{7} \mathrm{O}_{3} \mathrm{~S}: 468.1818$, found: 468.1814 .

4-(((2-((3-(morpholinomethyl)phenyl)amino)pyrimidin-4yl)amino)methyl)benzenesulfonamide (19): $18.8 \mathrm{mg}, 38 \%$ yield. ${ }^{1} \mathrm{H}$ NMR $\left(400 \mathrm{MHz}\right.$, Methanol- $\left.d_{4}\right) \delta 7.84(\mathrm{~d}, J=8.4 \mathrm{~Hz}, 2 \mathrm{H}), 7.77$ $(\mathrm{d}, J=6.0 \mathrm{~Hz}, 1 \mathrm{H}), 7.59(\mathrm{t}, J=2.0 \mathrm{~Hz}, 1 \mathrm{H}), 7.52-7.47(\mathrm{~m}, 2 \mathrm{H}), 7.36$ $(\mathrm{d}, J=8.2 \mathrm{~Hz}, 1 \mathrm{H}), 7.14(\mathrm{t}, J=7.8 \mathrm{~Hz}, 1 \mathrm{H}), 6.90(\mathrm{dt}, J=7.5,1.4 \mathrm{~Hz}$, $1 \mathrm{H}), 6.01(\mathrm{~d}, J=6.0 \mathrm{~Hz}, 1 \mathrm{H}), 4.70(\mathrm{~s}, 2 \mathrm{H}), 3.61(\mathrm{t}, J=4.7 \mathrm{~Hz}, 4 \mathrm{H})$, $3.35(\mathrm{~s}, 2 \mathrm{H}), 2.36(\mathrm{t}, J=4.5 \mathrm{~Hz}, 4 \mathrm{H}) .{ }^{13} \mathrm{C} \mathrm{NMR}(101 \mathrm{MHz}$, Methanol- $\left.d_{4}\right) \delta 163.16,159.74,154.25,144.48,142.16,140.34$, $137.04,128.07,127.30,125.95,122.68,120.45,118.38,97.18$, 66.23, 63.11, 53.14, 43.26. HPLC purity: 100\%. HRMS (ESI) $\left([\mathrm{M}+\mathrm{H}]^{+}\right)$Calcd. for $\mathrm{C}_{22} \mathrm{H}_{27} \mathrm{~N}_{6} \mathrm{O}_{3} \mathrm{~S}: 455.1865$, found: 453.20.

$N^{4}$-(2-(1H-imidazol-5-yl)ethyl)- $\boldsymbol{N}^{2}$-(3-

(morpholinomethyl)phenyl)pyrimidine-2,4-diamine (20): $21.0 \mathrm{mg}, 19 \%$ yield. ${ }^{1} \mathrm{H}$ NMR $\left(400 \mathrm{MHz}, \mathrm{DMSO}-d_{6}\right) \delta 11.81(\mathrm{~s}, 1 \mathrm{H})$, $8.92(\mathrm{~s}, 1 \mathrm{H}), 7.80(\mathrm{~d}, J=16.9 \mathrm{~Hz}, 2 \mathrm{H}), 7.61(\mathrm{~s}, 1 \mathrm{H}), 7.54(\mathrm{~s}, 1 \mathrm{H})$, $7.24(\mathrm{~s}, 1 \mathrm{H}), 7.12(\mathrm{t}, J=7.8 \mathrm{~Hz}, 1 \mathrm{H}), 6.79(\mathrm{~d}, J=10.4 \mathrm{~Hz}, 2 \mathrm{H}), 5.92$ $(\mathrm{d}, J=5.8 \mathrm{~Hz}, 1 \mathrm{H}), 3.54(\mathrm{~m}, 6 \mathrm{H}), 3.31(\mathrm{~s}, 2 \mathrm{H}), 2.79(\mathrm{~m}, 2 \mathrm{H}), 2.29$ (s, 4H). ${ }^{13} \mathrm{C}$ NMR (101 MHz, Methanol- $\left.d_{4}\right) \delta$ 163.14, 159.75, $153.70,140.60,137.24,134.91,134.58,128.07,122.50,120.29$, 118.18, 116.44, 97.18, 66.28, 63.20, 53.24, 40.31, 26.50. HPLC purity: $100 \%$. HRMS (ESI) $\left([\mathrm{M}+\mathrm{H}]^{+}\right)$Calcd. for $\mathrm{C}_{20} \mathrm{H}_{26} \mathrm{~N}_{7} \mathrm{O}$ : 380.2199, found: 378.24 .

Biological Evaluation. Enzymatic Assays. Eurofins kinase enzymatic radiometric assays were carried out at the $\mathrm{K}_{\mathrm{m}}=$ ATP at a single concentration $(1 \mu \mathrm{M})$ in duplicate for each kinase in Table 1 . Eurofins kinase enzymatic radiometric assays were carried out at the $\mathrm{K}_{\mathrm{m}}=$ ATP in dose-response (9-pt curve in duplicate) for each kinase with an $\mathrm{IC}_{50}$ value listed in Table 3 . Details about the substrate used, protein constructs, controls, and assay protocol for each kinase assay can be found at the Eurofins website: https://www.eurofinsdiscoveryservices.com.

Library-wide NanoBRET Assays. Human embryonic kidney (HEK293) cells (hypotriploid, female, fetal) were purchased from ATCC and grown in Dulbecco's Modified Eagle's medium (DMEM, Gibco) supplemented with $10 \%(\mathrm{v} / \mathrm{v})$ fetal bovine serum (FBS, Corning). Cells were incubated in $5 \% \mathrm{CO}_{2}$ at $37^{\circ} \mathrm{C}$ and passaged every 72 hours with trypsin. They were not allowed to reach confluency.

Constructs for NanoBRET measurements of DRAK1 (DRAK1NLuc), MARK3 (NLuc-MARK3), MARK4 (NLuc-MARK4), and TBK1 (NLuc-TBK1) included in Table 2 were kindly provided by Promega. NanoBRET assays were executed as described previously. ${ }^{17}$ Preferred NLuc orientations are indicated in parentheses after each construct. Assays were carried out in doseresponse as described by the manufacturer using $0.5 \mu \mathrm{M}$ of tracer $\mathrm{K}$ 9 for DRAK 1 and MARK 3 and $0.5 \mu \mathrm{M}$ of tracer K- 5 for MARK 4 and TBK1. Respective tracer titration curves that we generated for DRAK1, MARK3, and MARK4 can be found at https://darkkinome.org/data. ${ }^{33}$ Tracer titration curves for MARK3, MARK4, and TBK1 can also be found on the Promega website.

Kinome Screening. The scanMAX assay platform was used to assess the selectivity of each pyrimidine analog at $1 \mu \mathrm{M}$ at Eurofins DiscoverX Corporation. As described previously, this commercial assay platform screens against 403 wild-type human kinases and provides percent inhibition values. ${ }^{19}$ These inhibition values are captured in Table 1.

Specific NanoBRET Assay Follow-up. NanoBRET assays for the 6 kinases in Table 4 were carried out in dose-response in singlicate by Carna Biosciences. Assays were carried out according to the manufacturer's protocol.

Kinetic Solubility and Permeability (PAMPA). Kinetic solubility analysis was carried out from $10 \mathrm{mM}$ DMSO stocks of compounds in phosphate buffered saline solution (PBS) at $\mathrm{pH} 7.4$ by Analiza, Inc. Following $24 \mathrm{~h}$ incubation in a Millipore solubility filter plate, samples were vacuum filtered, and the filtrates collected for analysis. Filtrates were injected into the nitrogen detector for quantification via Total Chemiluminescent Nitrogen Determination (CLND). Filtrates were quantified with respect to a calibration curve generated using standards that span the dynamic range of the instrument. Calculated solubility values are corrected for background nitrogen present in the DMSO and the media.

PAMPA analysis was carried out by Analiza, Inc using a Corning Gentest Pre-coated PAMPA plate. DMSO stocks of compound diluted in PBS at $\mathrm{pH} 7.4$ were added to the Donor compartment of the plate, PBS at $\mathrm{pH} 7.4$ was added to the Acceptor compartment, and the plate was left to incubate for $5 \mathrm{~h}$. Both the Donor and Acceptor compartments were collected and analyzed by CLND. Donor and Acceptor samples were quantified using the calibration curve generated using standards that span the dynamic range of the instrument. Measured concentrations are corrected for background nitrogen present in the DMSO and the media. Concentration values from the Donor and Acceptor compartment are used in the calculation of the effective permeability of the compound. Solubility of the compound is determined experimentally rather than assuming full solubility.

Statistics. Standard error of the mean (SEM) was calculated for NanoBRET assays executed more than once. Calculated SEM is included alongside $\mathrm{IC}_{50}$ values in Table 2. 


\section{AUTHOR INFORMATION}

\section{Corresponding Author}

*E-mail: alison.axtman@unc.edu.

\section{Author Contributions}

All authors have given approval to the final version of the manuscript.

\section{Notes}

The authors declare no competing financial interest.

\section{ACKNOWLEDGMENT}

Constructs for NanoBRET measurements of DRAK1, MARK3, MARK4, and TBK1 were kindly provided by Promega. Coral was used to make the kinome tree depicted in our Table of Contents graphic. Coral was developed in the Phanstiel Lab at UNC: http://phanstiel-lab.med.unc.edu/CORAL. ${ }^{36}$ We used the TREEspot kinase interaction mapping software to prepare the kinome trees in Figure 1, and Supplemental Information: http://treespot.discoverx.com. We thank ChemSpace for synthetic support.

The Structural Genomics Consortium is a registered charity (number 1097737) that receives funds from AbbVie, Bayer Pharma AG, Boehringer Ingelheim, Canada Foundation for Innovation, Eshelman Institute for Innovation, Genome Canada, Genentech, Innovative Medicines Initiative (EU/EFPIA) [ULTRA-DD grant no. 115766], Janssen, Merck KGaA Darmstadt Germany, MSD, Novartis Pharma AG, Ontario Ministry of Economic Development and Innovation, Pfizer, São Paulo Research Foundation-FAPESP, Takeda, and Wellcome [106169/ZZ14/Z]. Research reported in this publication was supported in part by the NC Biotechnology Center Institutional Support Grant 2018-IDG-1030, NIH 1U24DK116204 and U54AG065187, DoD ALSRP award AL190107, and ALS Association Grant ID wa1127.

\section{ABBREVIATIONS}

DIPEA, $\mathrm{N}, \mathrm{N}$-diisopropylethylamine; DMSO, dimethyl sulfoxide; $\mathrm{HCl}$, hydrochloric acid; HPLC, high-performance liquid chromatography; $\mathrm{IC}_{50}$, half maximal inhibitory concentration; LCMS, liquid chromatography-mass spectrometry; $\mathrm{K}_{\mathrm{m}}$, Michaelis constant; LINCS, Library of Integrated Network-Based Cellular Signatures; NanoBRET, bioluminescence resonance energy transfer using Nanoluciferase; Nluc, Nanoluciferase; NMR, nuclear magnetic resonance; PAMPA, parallel artificial membrane permeability assay; $\mathrm{Pd} / \mathrm{C}$, palladium on carbon; $\mathrm{v} / \mathrm{v}$, volume for volume; w/w, weight for weight.

\section{REFERENCES}

(1) Meeta, S.; Nadeem, S. A review on biological importance of pyrimidines in the new era. Int J Pharm Pharm Sci 2016, 8, 8-21. (2) Roskoski, R., Jr. Properties of FDA-approved small molecule protein kinase inhibitors: A 2020 update. Pharmacol Res 2020, 152, 104609.

(3) Richters, A.; Basu, D.; Engel, J.; Ercanoglu, M. S.; BalkeWant, H.; Tesch, R.; Thomas, R. K.; Rauh, D. Identification and Further Development of Potent TBK1 Inhibitors. ACS Chem Biol 2015, 10, 289-298.

(4) Llona-Minguez, S.; Baiget, J.; Mackay, S. P. Small-molecule inhibitors of IאB kinase (IKK) and IKK-related kinases. Pharm Pat Anal 2013, 2, 481-98.
(5) Perrior, T. R.; Newton, G. K.; Stewart, M. R.; Aquil, R. Pyrimidine compounds as inhibitors of protein kinases IKK epsilon and/or TBK-1, processes for their preparation, and pharmaceutical compositions containing them. International Patent Application WO/2012010826-A1, 2012; Domainex Limited.

(6) Muvaffak, A.; Pan, Q.; Yan, H.; Fernandez, R.; Lim, J.; Dolinski, B.; Nguyen, T. T.; Strack, P.; Wu, S.; Chung, R.; Zhang, W.; Hulton, C.; Ripley, S.; Hirsch, H.; Nagashima, K.; Wong, K.K.; Jánne, P. A.; Seidel-Dugan, C.; Zawel, L.; Kirschmeier, P. T.; Middleton, R. E.; Morris, E. J.; Wang, Y. Evaluating TBK1 as a therapeutic target in cancers with activated IRF3. Mol Cancer Res 2014, 12, 1055-1066.

(7) Hutti, J. E.; Porter, M. A.; Cheely, A. W.; Cantley, L. C.; Wang, X.; Kireev, D.; Baldwin, A. S.; Janzen, W. P. Development of a High-Throughput Assay for Identifying Inhibitors of TBK1 and IKKe. PloS One 2012, 7, e41494.

(8) Crew, A. P.; Raina, K.; Dong, H.; Qian, Y.; Wang, J.; Vigil, D.; Serebrenik, Y. V.; Hamman, B. D.; Morgan, A.; Ferraro, C.; Siu, K.; Neklesa, T. K.; Winkler, J. D.; Coleman, K. G.; Crews, C. M. Identification and Characterization of Von Hippel-LindauRecruiting Proteolysis Targeting Chimeras (PROTACs) of TANK-Binding Kinase 1. J Med Chem 2018, 61, 583-598. (9) Oakes, J. A.; Davies, M. C.; Collins, M. O. TBK1: a new player in ALS linking autophagy and neuroinflammation. Mol Brain 2017, 10, 5.

(10) Freischmidt, A.; Wieland, T.; Richter, B.; Ruf, W.; Schaeffer, V.; Muller, K.; Marroquin, N.; Nordin, F.; Hubers, A.; Weydt, P.; Pinto, S.; Press, R.; Millecamps, S.; Molko, N.; Bernard, E.; Desnuelle, C.; Soriani, M. H.; Dorst, J.; Graf, E.; Nordstrom, U.; Feiler, M. S.; Putz, S.; Boeckers, T. M.; Meyer, T.; Winkler, A. S.; Winkelman, J.; de Carvalho, M.; Thal, D. R.; Otto, M.;

Brannstrom, T.; Volk, A. E.; Kursula, P.; Danzer, K. M.; Lichtner, P.; Dikic, I.; Meitinger, T.; Ludolph, A. C.; Strom, T. M.; Andersen, P. M.; Weishaupt, J. H. Haploinsufficiency of TBK1 causes familial ALS and fronto-temporal dementia. Nat Neurosci 2015, 18, 631-636.

(11) Hegde, R. N.; Chiki, A.; Petricca, L.; Martufi, P.; Arbez, N.; Mouchiroud, L.; Auwerx, J.; Landles, C.; Bates, G. P.; SinghBains, M. K.; Dragunow, M.; Curtis, M. A.; Faull, R. L.; Ross, C. A.; Caricasole, A.; Lashuel, H. A. TBK1 phosphorylates mutant Huntingtin and suppresses its aggregation and toxicity in Huntington's disease models. EMBO J 2020, 39, e104671.

(12) Verheijen, J.; van der Zee, J.; Gijselinck, I.; Van den Bossche, T.; Dillen, L.; Heeman, B.; Gómez-Tortosa, E.; Lladó, A.; Sanchez-Valle, R.; Graff, C.; Pastor, P.; Pastor, M. A.; Benussi, L.; Ghidoni, R.; Binetti, G.; Clarimon, J.; de Mendonça, A.; Gelpi, E.; Tsolaki, M.; Diehl-Schmid, J.; Nacmias, B.; Almeida, M. R.; Borroni, B.; Matej, R.; Ruiz, A.; Engelborghs, S.; Vandenberghe, R.; De Deyn, P. P.; Cruts, M.; Van Broeckhoven, C.; Sleegers, K. Common and rare TBK1 variants in early-onset Alzheimer disease in a European cohort. Neurobiol Aging 2018, 62, 245.e1-245.e7.

(13) Rodgers, G.; Austin, C.; Anderson, J.; Pawlyk, A.; Colvis, C.; Margolis, R.; Baker, J. Glimmers in illuminating the druggable genome. Nat Rev Drug Discov 2018, 17, 301-302.

(14) Krahn, A. I.; Wells, C.; Drewry, D. H.; Beitel, L. K.; Durcan, T. M.; Axtman, A. D. Defining the neural kinome: strategies and opportunities for small molecule drug discovery to target neurodegnerative diseases. ACS Chem Neurosci 2020, 11, 18711886.

(15) Annadurai, N.; Agrawal, K.; Džubák, P.; Hajdúch, M.; Das, $\mathrm{V}$. Microtubule affinity-regulating kinases are potential druggable targets for Alzheimer's disease. Cell Mol Life Sci 2017, 74, 41594169. 
(16) Katz, J. D.; Haidle, A.; Childers, K. K.; Zabierek, A. A.; Jewell, J. P.; Hou, Y.; Altman, M. D.; Szewczak, A.; Chen, D.; Harsch, A.; Hayashi, M.; Warren, L.; Hutton, M.; Nuthall, H.; Su, H. P.; Munshi, S.; Stanton, M. G.; Davies, I. W.; Munoz, B.; Northrup, A. Structure guided design of a series of selective pyrrolopyrimidinone MARK inhibitors. Bioorg Med Chem Lett 2017, 27, 114-120.

(17) Wells, C.; Couñago, R. M.; Limas, J. C.; Almeida, T. L.; Cook, J. G.; Drewry, D. H.; Elkins, J. M.; Gileadi, O.; Kapadia, N. R.; Lorente-Macias, A.; Pickett, J. E.; Riemen, A.; Ruela-de-Sousa, R. R.; Willson, T. M.; Zhang, C.; Zuercher, W. J.; Zutshi, R.; Axtman, A. D. SGC-AAK1-1: A Chemical Probe Targeting AAK1 and BMP2K. ACS Med Chem Lett 2019, 11, 340-345.

(18) Agajanian, M. J.; Walker, M. P.; Axtman, A. D.; Ruela-deSousa, R. R.; Serafin, D. S.; Rabinowitz, A. D.; Graham, D. M.; Ryan, M. B.; Tamir, T.; Nakamichi, Y.; Gammons, M. V.; Bennett, J. M.; Counago, R. M.; Drewry, D. H.; Elkins, J. M.; Gileadi, C.; Gildadi, O.; Godoi, P. H.; Kapadia, N.; Muller, S.; Santiago, A. S.; Sorrell, F. J.; Wells, C. I.; Fedorov, O.; Willson, T. M.; Zuercher, W. J.; Major, M. B. WNT activates the AAK1 kinase to promote clathrin-mediated endocytosis of LRP6 and establish a negative feedback loop. Cell Rep 2019, 26, 79-83.

(19) Davis, M. I.; Hunt, J. P.; Herrgard, S.; Ciceri, P.; Wodicka, L. M.; Pallares, G.; Hocker, M.; Treiber, D. K.; Zarrinkar, P. P. Comprehensive analysis of kinase inhibitor selectivity. Nat Biotechnol 2011, 29, 1046-1051.

(20) Clark, K.; Peggie, M.; Plater, L.; Sorcek, Ronald J.; Young, Erick R. R.; Madwed, Jeffrey B.; Hough, J.; McIver, Edward G.; Cohen, P. Novel cross-talk within the IKK family controls innate immunity. Biochem J 2011, 434, 93-104.

(21) McIver, E. G.; Bryans, J.; Birchall, K.; Chugh, J.; Drake, T.; Lewis, S. J.; Osborne, J.; Smiljanic-Hurley, E.; Tsang, W.; Kamal, A.; Levy, A.; Newman, M.; Taylor, D.; Arthur, J. S. C.; Clark, K.; Cohen, P. Synthesis and structure-activity relationships of a novel series of pyrimidines as potent inhibitors of TBK1/IKK $\varepsilon$ kinases. Bioorg Med Chem Lett 2012, 22, 7169-7173.

(22) Petherick, K. J.; Conway, O. J.; Mpamhanga, C.; Osborne, S. A.; Kamal, A.; Saxty, B.; Ganley, I. G. Pharmacological inhibition of ULK1 kinase blocks mammalian target of rapamycin (mTOR)dependent autophagy. J Biol Chem 2015, 290, 11376-11383.

(23) Feldman, R. I.; Wu, J. M.; Polokoff, M. A.; Kochanny, M. J.; Dinter, H.; Zhu, D.; Biroc, S. L.; Alicke, B.; Bryant, J.; Yuan, S.; Buckman, B. O.; Lentz, D.; Ferrer, M.; Whitlow, M.; Adler, M.; Finster, S.; Chang, Z.; Arnaiz, D. O. Novel small molecule inhibitors of 3-phosphoinositide-dependent kinase-1. J Biol Chem 2005, 280, 19867-19874.

(24) Stathias, V.; Turner, J.; Koleti, A.; Vidovic, D.; Cooper, D.; Fazel-Najafabadi, M.; Pilarczyk, M.; Terryn, R.; Chung, C.; Umeano, A.; Clarke, D. J. B.; Lachmann, A.; Evangelista, J. E.; Ma'ayan, A.; Medvedovic, M.; Schürer, S. C. LINCS Data Portal 2.0: next generation access point for perturbation-response signatures. Nucleic Acids Res 2019, 48, D431-D439.

(25) Thomson, D. W.; Poeckel, D.; Zinn, N.; Rau, C.; Strohmer, K.; Wagner, A. J.; Graves, A. P.; Perrin, J.; Bantscheff, M.; Duempelfeld, B.; Kasparcova, V.; Ramanjulu, J. M.; Pesiridis, G. S.; Muelbaier, M.; Bergamini, G. Discovery of GSK8612, a Highly Selective and Potent TBK1 Inhibitor. ACS Med Chem Lett 2019, $10,780-785$.

(26) Faisal, M.; Kim, J. H.; Yoo, K. H.; Roh, E. J.; Hong, S. S.; Lee, S. H. Development and Therapeutic Potential of NUAKs Inhibitors. J Med Chem 2021, 64, 2-25.

(27) Drewes, G.; Ebneth, A.; Preuss, U.; Mandelkow, E.-M.; Mandelkow, E. MARK, a Novel Family of Protein Kinases That
Phosphorylate Microtubule-Associated Proteins and Trigger Microtubule Disruption. Cell 1997, 89, 297-308.

(28) Lasagna-Reeves, C. A.; de Haro, M.; Hao, S.; Park, J.; Rousseaux, M. W.; Al-Ramahi, I.; Jafar-Nejad, P.; Vilanova-Velez, L.; See, L.; De Maio, A.; Nitschke, L.; Wu, Z.; Troncoso, J. C.; Westbrook, T. F.; Tang, J.; Botas, J.; Zoghbi, H. Y. Reduction of Nuak1 Decreases Tau and Reverses Phenotypes in a Tauopathy Mouse Model. Neuron 2016, 92, 407-418.

(29) Shi, B.; Conner, S. D.; Liu, J. Dysfunction of endocytic kinase AAK1 in ALS. Int J Mol Sci 2014, 15, 22918-22932.

(30) Vasta, J. D.; Corona, C. R.; Wilkinson, J.; Zimprich, C. A.; Hartnett, J. R.; Ingold, M. R.; Zimmerman, K.; Machleidt, T.; Kirkland, T. A.; Huwiler, K. G.; Ohana, R. F.; Slater, M.; Otto, P.; Cong, M.; Wells, C. I.; Berger, B. T.; Hanke, T.; Glas, C.; Ding, K.; Drewry, D. H.; Huber, K. V. M.; Willson, T. M.; Knapp, S.; Muller, S.; Meisenheimer, P. L.; Fan, F.; Wood, K. V.; Robers, M. B. Quantitative, Wide-Spectrum Kinase Profiling in Live Cells for Assessing the Effect of Cellular ATP on Target Engagement. Cell Chem Biol 2018, 25, 206-214.

(31) Wells, C. I.; Al-Ali, H.; Andrews, D. M.; Asquith, C. R. M.; Axtman, A. D.; Dikic, I.; Ebner, D.; Ettmayer, P.; Fischer, C.; Frederiksen, M.; Futrell, R. E.; Gray, N. S.; Hatch, S. B.; Knapp, S.; Lücking, U.; Michaelides, M.; Mills, C. E.; Müller, S.; Owen, D.; Picado, A.; Saikatendu, K. S.; Schröder, M.; Stolz, A.; Tellechea, M.; Turunen, B. J.; Vilar, S.; Wang, J.; Zuercher, W. J.; Willson, T. M.; Drewry, D. H. The Kinase Chemogenomic Set (KCGS): An Open Science Resource for Kinase Vulnerability Identification. Int J Mol Sci 2021, 22, 566.

(32) Drewry, D. H.; Wells, C. I.; Andrews, D. M.; Angell, R.; AlAli, H.; Axtman, A. D.; Capuzzi, S. J.; Elkins, J. M.; Ettmayer, P.; Frederiksen, M.; Gileadi, O.; Gray, N.; Hooper, A.; Knapp, S.; Laufer, S.; Luecking, U.; Michaelides, M.; Muller, S.; Muratov, E.; Denny, R. A.; Saikatendu, K. S.; Treiber, D. K.; Zuercher, W. J.; Willson, T. M. Progress towards a public chemogenomic set for protein kinases and a call for contributions. PloS One 2017, 12, e0181585.

(33) Berginski, M. E.; Moret, N.; Liu, C.; Goldfarb, D.; Sorger, Peter K.; Gomez, S. M. The Dark Kinase Knowledgebase: an online compendium of knowledge and experimental results of understudied kinases. Nucleic Acids Res 2021, 49, D529-D535. (34) Fensome, A.; Ambler, C. M.; Arnold, E.; Banker, M. E.; Clark, J. D.; Dowty, M. E.; Efremov, I. V.; Flick, A.; Gerstenberger, B. S.; Gifford, R. S.; Gopalsamy, A.; Hegen, M.; Jussif, J.; Limburg, D. C.; Lin, T. H.; Pierce, B. S.; Sharma, R.; Trujillo, J. I.; Vajdos, F. F.; Vincent, F.; Wan, Z.-K.; Xing, L.; Yang, X.; Yang, X. Design and optimization of a series of 4-(3azabicyclo[3.1.0] hexan-3-yl)pyrimidin-2-amines: Dual inhibitors of TYK2 and JAK1. Bioorg Med Chem 2020, 28, 115481.

(35) Fensome, A.; Ambler, C. M.; Arnold, E.; Banker, M. E.; Brown, M. F.; Chrencik, J.; Clark, J. D.; Dowty, M. E.; Efremov, I. V.; Flick, A.; Gerstenberger, B. S.; Gopalsamy, A.; Hayward, M. M.; Hegen, M.; Hollingshead, B. D.; Jussif, J.; Knafels, J. D.; Limburg, D. C.; Lin, D.; Lin, T. H.; Pierce, B. S.; Saiah, E.; Sharma, R.; Symanowicz, P. T.; Telliez, J.-B.; Trujillo, J. I.; Vajdos, F. F.; Vincent, F.; Wan, Z.-K.; Xing, L.; Yang, X.; Yang, $\mathrm{X}$.; Zhang, L. Dual Inhibition of TYK2 and JAK1 for the Treatment of Autoimmune Diseases: Discovery of ((S)-2,2Difluorocyclopropyl)((1R,5S)-3-(2-((1-methyl-1H-pyrazol-4yl)amino)pyrimidin-4-yl)-3,8-diazabicyclo[3.2.1] octan-8yl)methanone (PF-06700841). J Med Chem 2018, 61, 8597-8612. (36) Metz, K. S.; Deoudes, E. M.; Berginski, M. E.; Jimenez-Ruiz, I.; Aksoy, B. A.; Hammerbacher, J.; Gomez, S. M.; Phanstiel, D. H. Coral: Clear and Customizable Visualization of Human Kinome Data. Cell Syst 2018, 7, 347-350.e1. 